\title{
Whole Genome Sequencing and Expression Analysis of ToxA in Bipolaris Sorokiniana Provides Discernment of Pathogenicity Causing Spot Blotch of Wheat
}

Rashmi Aggarwal ( $\square$ rashmi.aggarwal2@gmail.com )

ICAR-Indian Agricultural Research Institute

\section{Shweta Agarwal}

ICAR-Indian Agricultural Research Institute

\section{Sapna Sharma}

ICAR-Indian Agricultural Research Institute

Malkhan Singh Gurjar

ICAR-Indian Agricultural Research Institute

Bishnu Maya Bashyal

ICAR-Indian Agricultural Research Institute

\section{Atmakuri Ramakrishna Rao}

ICAR- Indian Council of Agricultural Research

\section{Sarika Sahu}

ICAR- IASRI

\section{Prachi Jain}

ICAR-Indian Agricultural Research Institute

Mahender Singh Saharan

ICAR-Indian Agricultural Research Institute

\section{Research Article}

Keywords: Bipolaris sorokiniana, ToxA, Tsn1, whole genome sequence, qPCR, spot blotch, wheat

Posted Date: August 30th, 2021

DOl: https://doi.org/10.21203/rs.3.rs-677095/v1

License: (c) (1) This work is licensed under a Creative Commons Attribution 4.0 International License. Read Full License 


\section{Abstract}

Background: Spot blotch disease of wheat caused by Bipolaris sorokiniana Boerma (Sacc.) is an emerging problem in South Asian countries. In this study, whole genome of highly virulent isolate of Bipolaris sorokiniana (BS112) was sequenced, pathogenicity related gene(s) were identified and role of ToxA gene in spot blotch disease development was established.

Results: Bipolaris sorokiniana isolate BS112 infecting wheat was sequenced using hybrid assembly approach. The assembly size of the genome was $35.64 \mathrm{Mb}$ (GenBank accession number RCTM00000000) with GC content of $50.2 \%$, providing coverage of $97.6 \%$ on reference ND90Pr genome. Average gene density predicted was 250-300 genes/Mb. A total of 235 scaffolds were obtained using pyScaf assembler with $N_{50}$ of $16,54,800$ bp. In addition, 152 transcription factors involved in various biological processes were identified and a total of 682 secretory proteins were predicted using secretome analysis. ToxA gene (535bp) was analyzed and identified in the genome of $B$. sorokiniana which revealed $100 \%$ homology with ToxA gene of Pyrenophora tritici repentis. Further, ToxA gene was amplified, sequenced and validated in the 39 isolates of $B$. sorokiniana which confirmed the presence of ToxA gene in all the isolates of $B$. sorokiniana. All these ToxA sequences were submitted in NCBI database (MN601358-MN601396). As ToxA gene interacts with Tsn1 gene of host, 13 wheat genotypes were evaluated for the Tsn 1 gene and five genotypes (38.4\%) were found to be Tsn1 positive with more severe necrotic lesions compared to Tsn 1 negative wheat genotypes. In vitro expression analysis of ToxA gene in $B$. sorokiniana isolate (BS112) using qPCR revealed maximum upregulation (14.67 fold) at $1^{\text {st }}$ day after inoculation (DAl). Further, in planta expression analysis of ToxA gene in Tsn 1 positive and Tsn1 negative genotypes, Agra local and Chiriya 7 respectively was also conducted. Results revealed maximum expression (7.89 fold) of ToxA gene in Tsn 1 positive genotype, Agra local at $5^{\text {th }}$ DAl compared to $T s n 1$ negative genotype Chiriya 7 which showed minimum expression $(0.048$ fold $)$ at $5^{\text {th }}$ DAl.

Conclusions: Full genome of $B$. sorokiniana was sequenced; secreted proteins and virulence genes were identified in the genome. ToxA gene was validated in thirty nine isolates of $B$. sorokiniana. In planta ToxATsn 1 interaction studies established that spot blotch disease is more severe in Tsn 1 positive genotypes. This genomic resource will provide a new insight into better understanding and management of spot blotch disease and $B$. sorokiniana of wheat.

\section{Background}

Wheat is considered as staple and a leading source of a protein in human food. Wheat production throughout North and South Asia is affected by several abiotic and biotic stresses. Among biotic stresses, the important wheat disease throughout North and South Asia is spot blotch, caused by Bipolaris sorokiniana. Various other diseases are also caused by this fungus like foliar blight, common root rot, black point and seedling blight of barley and wheat [1,2]. However, spot blotch of wheat is majorly the most important diseases which is prevalent in high temperature and humidity areas [3]. Almost 9 million ha of land is affected by spot blotch in India [4] causing 14.9\% (approx.) of yield loss [5, 6]. B. sorokiniana 
is an aggressive fungal pathogen that causes small, dark brown colored lesions on leaves with the length of 1-2 mm without chlorotic margin. These lesions become dark brown in 4 to 5 days and extend to several centimeters in susceptible genotypes inducing leaf abscission. Environmental factors contribute an important role in disease severity. In India, late sown wheat crop is highly vulnerable to this disease due to temperature which ranges between $26-30^{\circ} \mathrm{C}[7]$.

In the past, it is believed that spot blotch is caused due to compound of three species i.e. Alternaria triticina, Helminthosporium sativum and Pyrenophora tritici-repentis [8]. But later study revealed that it is mainly caused by a hemibiotroph aggressive pathogen $B$. sorokiniana. At the seedling stage this disease appears and increases as plant grows with more severity. As this pathogen infects the plant, conidium germination was observed on the leaf surfaces followed by a germ tube to form a rudimentary appresorium. This infection hyphae either directly penetrate the cuticle and epidermal cell wall or through stomata $[9,10]$. Many non-selective toxins and hydrolytic enzymes are produced by $B$. sorokiniana which form lesions on the leaf, leading to leaf abscission [11, 12].

Metabolites produced by $B$. sorokiniana are considered as toxins which play an important role in disease development. During 1990, ToxA was discovered in Parastagonospora nodorum, causing septoria nodorum blotch (SNB) which horizontally got transferred to Pyrenophora tritici repentis causing tan spot $[13,14]$. ToxA was reported to be unique to Pyrenophora tritici repentis but not conserved in its genome [15]. Recently, ToxA gene was discovered in Australian B. sorokiniana isolates [16] and it was also exists in the $B$. sorokiniana population in the winter wheat region of the United States [17]. According to Gupta et al. [18] effector triggered susceptibility was identified in wheat- $B$. sorokiniana pathosystem where ToxA (virulence gene) utilizes Tsn 1 (sensitivity gene) in the host, which helps fungus to cause disease by invading the host. Necrosis was induced on wheat leaves of ToxA sensitive wheat genotypes (possessing the Tsn1 susceptibility gene) [19]. According to McDonald et al. [16] also presence of sensitivity gene Tsn 1 in wheat generally helps a ToxA positive pathogen to cause spot blotch disease and ToxA functions in a Tsn 1 dependent manner. In general, the ToxA-Tsn 1 system is a prototype of an inverse gene-for-gene relationship [20].

Present study was undertaken to analyze the genome, its function and to provide new insights into the genome of B. sorokiniana Indian isolate BS112 (collected from BHU, Uttar Pradesh; Accession number: MN601379). Here, three genome sequences of Bipolaris species were compared with the genome sequence of $B$. sorokiniana strain BS112. Further, genes involved in carbohydrate-active enzymes, pathogenesis and secondary metabolism have been identified and validated. The genome was also analyzed for ToxA and its copy numbers in the genome. Till now six genomes of $B$. sorokiniana were sequenced, including Indian isolate BS112 of B. sorokiniana. Recently, Aggarwal et al. [21] announced the draft genome of highly virulent strain of $B$. sorokiniana (BS112) (RCTM00000000) with a genome assembly size of $35.64 \mathrm{Mb}$. However, comparative genomic information along with other Bipolaris species is not available. This whole genome de novo sequence of Indian wheat isolate of $B$. sorokiniana represents the first genome scale assembly for $B$. sorokiniana. The identification of virulence gene Tox $A$ 
in wheat isolates of $B$. sorokiniana, led us to further characterize its expression in different Indian wheat genotypes.

\section{Results}

\section{Genomic features of B. sorokiniana}

Whole genome sequencing of $B$. sorokiniana (BS112) was performed using Illumina Hiseq (SRX6673824), Oxford Nanopore Sequencing (SRX6100476) and lon-Torrent platform (SRX6673825) technologies. For the Illumina library preparation TruSeq DNA PCR free kit was used with an insert size of $350 \mathrm{bp}$ and $150 \mathrm{bp}$ read size from both the ends. As a result of which $36,915,848$ paired end reads were found (Table 1).

\begin{tabular}{|ll|}
\hline \multicolumn{2}{|c|}{ Illumina Sequencing Statistics } \\
\hline Sample name & BS 112 \\
\hline Raw read & 36915848 \\
\hline Trimmed read & 35218897 \\
\hline Chemistry & $101 * 2$ \\
\hline Platform & Illumina Hiseq \\
\hline Library type & Paired end \\
\hline Total_Raw_Data (Nucleotide size) & 3728500648 \\
\hline Total_Trimmed_data (Nucleotide size) & 3728500648 \\
\hline
\end{tabular}

Ion Xpress plus fragment library kit was used for fungal DNA shearing enzymatically into suitably sized fragments for lon torrent library. A target peak of 330bp was selected for adapter ligated library using Egel seize select $2 \%$ agarose gel (Invitrogen Corporation, USA). Finally, lon plus fragment library kit (Life technologies, USA) was used for adapter ligation, size selected library was amplified and the run was performed on an Ion PGM system version 1. As a result, 8,45,589 reads were obtained. Oxford Nanopore Platform library preparation was done using a ligation sequencing kit (SQK-LSK 108) from Oxford Nanopore Technologies; as a result of which 5,60,150 reads were generated, including 1,14,369 as maximum read length and 171 as minimum read length (Table 2). 


\begin{tabular}{|ll|}
\hline \multicolumn{2}{|c|}{ Nanopore Sequencing Statistics } \\
\hline Summary & Count \\
\hline Reads Generated & 560150 \\
\hline Maximum Read length & 114369 \\
\hline Minimum read length & 171 \\
\hline Average read length & $4804.4 \pm 5450.4$ \\
\hline Median Read length & 8617.5 \\
\hline Total read length & 2691210065 \\
\hline
\end{tabular}

All three types of sequencing reads were incorporated in hybrid genome assembly pipeline using the MaSuRCA tool version 3.2.2 (7) to produce a draft genome assembly of $35.64 \mathrm{Mb}$ with a GC content of $50.2 \%$ (Table 3 ) and the contigs were organized into scaffolds using pyScaf version 3 (https://pypi.org/search/?q_PyScaf_version_3). A total of 235 scaffolds were produced with the $\mathrm{N}_{50}$ scaffolds of $3501266 \mathrm{bp}$ and an average scaffold of 1,51,674.3 $\pm 4,98,379.7 \mathrm{bp}$ (Table 4).

\begin{tabular}{|ll|}
\hline \multicolumn{2}{|c|}{ Table 3 } \\
\hline Hybrid genome Assembly Statistics using MaSuRCA tool \\
\hline Assembler & MaSuRCA \\
\hline Contigs generated & 627 \\
\hline Maximum Contig length & $4,93,103$ \\
\hline Minimum Contig length & 1518 \\
\hline Average contig length & $51,819.0 \pm 70,246.9$ \\
\hline Total Contigs length & $3,24,90,483$ \\
\hline$N_{50}$ value & $1,20,114$ \\
\hline
\end{tabular}




\begin{tabular}{|ll|}
\multicolumn{2}{|c|}{ Scaffolding using pyScaf (final hybrid assembly) } \\
\hline Assembler & pyScaf \\
\hline Scaffolds generated & 235 \\
\hline Maximum scaffold length & $35,01,266 \mathrm{bp}$ \\
\hline Minimum scaffold length & $1553 \mathrm{bp}$ \\
\hline Average scaffold length & $1,51,674.3 \pm 4,98,379.7 \mathrm{bp}$ \\
\hline Total scaffolds length & $3,56,43,459 \mathrm{bp}$ \\
\hline Total number of non - ATGC characters & $31,79,647$ \\
\hline Percentage of non-ATGC characters & 8.921 \\
\hline$N_{50}$ value & $16,54,800$ \\
\hline
\end{tabular}

\section{Gene prediction and gene ontology annotation}

A total number of 10,460 protein-coding genes were identified with an average gene size of $435-545 \mathrm{bp}$. Total proteins annotated against fungal database was 10,141 and unannotated proteins were 391 (Additional file 1). An average gene density was 250-300 genes/ $\mathrm{Mb}$ in the genome of $B$. sorokiniana and $8,506 \mathrm{bp}$ and $35 \mathrm{bp}$ were the maximum and minimum sizes of the genes, respectively. To classify the putative pathogenicity-related genes, 3,627 genes were annotated against the pathogen-host interaction database (PHI database). Based on the homology of pathogenicity proteins, 1,475 genes were related to reduced virulence, 1,281 genes to unaffected pathogenicity, 264 genes to loss of pathogenicity, 174 genes related to lethal and 117 genes related to unaffected pathogenicity reduced virulence (Fig. 1).

In gene ontology (G0) from a total of 2,788 protein-coding genes 1,024 genes were assigned to 'Biological Process' which included 217 genes for transmembrane transport, 187 genes for carbohydrate metabolic process, 182 genes for metabolic process (Fig. 2a). Whereas, 1,274 genes assigned for 'Molecular Function', 432 genes were related to ATP binding, 356 genes to Zinc ion binding, 245 to DNA binding, 204 to oxido reductase activity (Fig. 2b). A total of 1,814 genes were assigned for 'Cellular Component' which included 493 genes for integral component of membrane, 394 for nucleus, 188 for cytoplasm, 93 for intracellular component (Fig. 2c) (Additional file 2).

\section{Phylogenetic inferences}

The evolutionary relationship of five species of Bipolaris, two isolates of B. sorokiniana along with one isolate of Pyrenophora tritici-repentis (Accession number MH017419.1) determined through phylogenetic analysis (Fig. 3a) revealed 95-99\% similarity in all the species of Bipolaris which were grouped in a single major cluster. B. sorokiniana query sample (BS112), B. sorokiniana (ND90Pr), B. maydis 
(Accession no. NW_014024938, Strain-ATCC 48331) are grouped together in subcluster 1 showing closer similarity. Whereas, B. oryzae, B. zeicola and B. victoriae (Accession no. GCA_000527765, Strain- F13) were grouped together in subcluster 2 .

\section{Comparative genome annotation between the Bipolaris species}

The orthologous gene families among four Bipolaris species including B. victoriae (Accession no. GCA_000527765.1, Strain- F13), B. oryzae (Accession no. GCA_000523455.1, Strain- ATCC 44560), $B$. sorokiniana and $B$. zeicola (Accession no. GCA_000523435.1, Strain-26-R-13) were identified using OrthoVenn (Fig. 3b). A total number of 11,938 clusters and 8,370 single copy gene clusters in $B$. sorokiniana genome were identified in four species which revealed that 8,674 gene families are common in Bipolaris species. Orthologous cluster study reveals 98 common clusters between $B$. sorokiniana and $B$. victoriae, 115 common clusters between $B$. sorokiniana and $B$. oryzae and 74 common clusters between $B$. sorokiniana and $B$. zeicola. Further, 21 unique clusters were identified in $B$. sorokiniana, 25 in B. victoriae, 13 in B. oryzae and 5 in B. zeicola (Additional file 3).

\section{Identification of SSRs (Simple Sequence Repeats) and SNPs (Single Nucleotide Polymorphism)}

A total of 5996 SSRs were identified with the total size of 35.64Mb (Fig. 4). Out of these, 617 compound SSRs were identified. These SSRs were classified as mono, di, tri, tetra, penta, and hexa nucleotide in the genome of $B$. sorokiniana. The most abundant SSR type was tetra nucleotide in $B$. sorokiniana genome with 2,248 in number (63\% of all SSRs) (Additional file 4). Total number of variants detected through Sam-tools were 93,122 . Additionally, a total of 88,672 SNPs and 4,450 Indels were also identified in the genome (Additional file 5).

\section{Protein domain analysis}

Pfam were scanned to the predicted proteins of $B$. sorokiniana protein domain collection. A total of 12,082 proteins domains were estimated from derived protein sequences. 3,357 total protein family was identified from which top Pfam domain "WD domain, G-beta repeat" is involved in transcription factors (422 proteins). Super family MSF domain (203 proteins) is the second top most Pfam domain associated with transportation of solutes involved in chemiosmotic ion gradients. In addition, Ankyrin repeat contains 138 proteins of Pfam domain, is highly involved in diverse set of cellular functions (Fig. 5) (Additional file 6).

\section{Prediction and analysis of the attributes of B. sorokiniana secretome}


Among 10,460 predicted proteins, 1,078 proteins were annoted as classical secretory proteins by SignalP v4.1 [22] (http://www.cbs.dtu.dk/servi ces/SignalP/), while 1,134 proteins were classified as secretory proteins by TargetP v1.11 (http://www.cbs.dtu.dk/servi ces/TargetP/). To predict the total secretome SignalP v4.1 and TargetP v1.1 was combined initially, removing all duplicate segments and 1,184 unique proteins having secretory signatures were generated using TMHMM software. Within the gene set, 935 secretory proteins containing zero transmembrane domain ( $\mathrm{TmHmm} 0$ ) having 92 highly probable glycosylphosphatidylinositol (GPI) anchor containing sequences and 47 proteins containing one transmembrane domain ( $\mathrm{TmHmm} 1)$ were identified. A total of 982 transmembrane proteins from the protein data set screened through WoLFPSORT using "run WoLFPSORT v. 0.2 " for the confirmation of secretory protein, resulted in identification of 682 secretory proteins (Table 5). From this total 682 proteins, 573 were assigned to GO terms in 3 categories namely; molecular function (343), biological process (88) and cellular component (137) (Fig. 6).

Table 5

Secretome prediction analysis in the genome of $B$. sorokiniana

\begin{tabular}{|ll|}
\hline Genome & Number of proteins \\
\hline SignalP v5.0 & 1078 \\
\hline TargetP & 1134 \\
\hline Uniq merged (SignalP v5.0 \& targetP) & 1184 \\
\hline TMHMMv2.0 with 0 transmembrane & 935 \\
\hline TMHMMv2.0 with 1 transmembrane & 47 \\
\hline Zero transmembrane domain with GPI & 92 \\
\hline WoLFPSORT & 682 \\
\hline
\end{tabular}

Using CAZy database, 216 CAZy enzymes were predicted specifically, with GH (Glycoside hydrolases) families being the most copious (Fig. 7). Forty five GH families were spotted having 78 total genes, from which 7 families showed presence of more than 2 genes including $\mathrm{GH} 5$ having maximum number of genes ( 6 genes) followed by GH3 (5 genes), GH7 (5 genes), GH43 (5 genes), GH10 (4 genes), GH11 (4 genes) and GH35 (3 genes). Seventy six genes from 18 CBM (Carbohydrate Binding Modules) family were identified, from which 8 CBM families' showed more than 2 genes including CBM1 (30 genes), CBM2 (8 genes), CBM18 (8 genes), CBM13 (5 genes), CBM6 (3 genes), CBM32 (3 genes), CBM35 (3 genes) and CBM60 (3 genes). Sixteen genes were identified from $6 \mathrm{CE}$ (Carbohydrate esterase) families, from which maximum number of genes were identified for CE5 ( 5 genes) followed by CE1 and CE4 3 genes each. Further, 41 genes from 10 AA (Auxiliary activities) family were identified, from which maximum number of genes were present in AA3 (11 genes) followed by AA9 (10 genes), AA1 (5 genes), AA5 (4 genes) and AA1 (3 genes). Further, 9 genes were identified from 4 families of PL (Polysaccharide 
lyases), which includes maximum number of genes in PL3 (3 genes) and PL4 (3 genes). From all of them, CBM1, GH5 and AA3 families were most ample (Additional file 7).

\section{ToxA gene analysis in the genome of B. sorokiniana}

Screening of ToxA gene in the genome of B. sorokiniana (RCTM01000005.1) using BLAST $\mathrm{n}$ revealed three copies of ToxA gene in this pathogen which was identified in different scaffolds i. e. (a) scaffold 7180000000228.1880955; start- 1236214, end-1236802, (b) scaffold00139 99.755; start-408, end-747 and (C) scaffold00139 100.000; start-133, end-246.

ToxA gene sequencing and phylogenetic analysis in Indian population of B. sorokiniana

ToxA gene got amplified in thirty nine $B$. sorokiniana isolates collected from different locations in India (Table 6), which confirmed the presence of ToxA in all the isolates studied. The coding length of ToxA gene was $535 \mathrm{bp}$ (excluding intron) which was exactly same in all the $B$. sorokiniana isolates (Fig. 8a). All these ToxA sequences were submitted in NCBI database under the accession numbers (MN601358MN601396) (Table 6). 
Table 6

Details of Bipolaris sorokiniana isolates from different regions of India

\begin{tabular}{|c|c|c|c|c|c|}
\hline S.No & $\begin{array}{l}\text { Agroclimatic } \\
\text { zone }\end{array}$ & Location/state & Centre name & $\begin{array}{l}\text { Designated } \\
\text { name of isolate }\end{array}$ & $\begin{array}{l}\text { Accession } \\
\text { no. }\end{array}$ \\
\hline 1 & North Hills zone & $\begin{array}{l}\text { Pantnagar } \\
\text { (Uttarakhand) }\end{array}$ & & BS-1 & MN601358 \\
\hline 2 & $\begin{array}{l}\text { North Western } \\
\text { plains zone }\end{array}$ & $\begin{array}{l}\text { Asandh, panipat } \\
(\mathrm{HR})\end{array}$ & Asandh - 1 & BS-3 & MN601359 \\
\hline 3 & $\begin{array}{l}\text { North Eastern } \\
\text { plains zone }\end{array}$ & $\begin{array}{l}\text { Faziabad, } \\
\text { Ayodhya (UP) }\end{array}$ & Faizabad-1 & BS-4 & MN601360 \\
\hline 4 & $\begin{array}{l}\text { North Western } \\
\text { plain zone }\end{array}$ & Karnal (HR) & DWR-1,BS-2 & BS-6 & MN601361 \\
\hline 5 & North Hills zone & $\begin{array}{l}\text { Almora } \\
\text { (Uttarakhand) }\end{array}$ & Almora UPAS-1 & BS-11 & MN601362 \\
\hline 6 & $\begin{array}{l}\text { North Western } \\
\text { plains zone }\end{array}$ & Karnal (HR) & Jaipur-6 & BS-14 & MN601363 \\
\hline 7 & $\begin{array}{l}\text { North Eastern } \\
\text { plains zone }\end{array}$ & $\begin{array}{l}\text { Faziabad, } \\
\text { Ayodhya (UP) }\end{array}$ & Faizabad-1 & BS-27 & MN601364 \\
\hline 8 & $\begin{array}{l}\text { North Eastern } \\
\text { plains zone }\end{array}$ & $\begin{array}{l}\text { Faziabad, } \\
\text { Ayodhya (UP) }\end{array}$ & Faizabad-3 & BS-29 & MN601365 \\
\hline 9 & $\begin{array}{l}\text { North Eastern } \\
\text { plains zone }\end{array}$ & $\begin{array}{l}\text { Faziabad, } \\
\text { Ayodhya (UP) }\end{array}$ & Faizabad-4 & BS-30 & MN601366 \\
\hline 10 & $\begin{array}{l}\text { North Eastern } \\
\text { plains zone }\end{array}$ & $\begin{array}{l}\text { Faziabad, } \\
\text { Ayodhya (UP) }\end{array}$ & Faizabad-6 & BS-32 & MN601367 \\
\hline 11 & $\begin{array}{l}\text { North Eastern } \\
\text { plains zone }\end{array}$ & $\begin{array}{l}\text { Faziabad, } \\
\text { Ayodhya (UP) }\end{array}$ & Faizabad-7 & BS-50 & MN601368 \\
\hline 12 & North Hills zone & $\begin{array}{l}\text { Almora } \\
\text { (Uttarakhand) }\end{array}$ & Almora UPAS-1 & BS-54 & MN601369 \\
\hline 13 & Peninsular zone & $\begin{array}{l}\text { Mahabaleshwar } \\
\text { (MS) }\end{array}$ & Mahabaleshwar & BS-65 & MN601370 \\
\hline 14 & Peninsular zone & $\begin{array}{l}\text { Mahabaleshwar } \\
\text { (MS) }\end{array}$ & $\begin{array}{l}\text { Mahabaleshwar } \\
-1 a\end{array}$ & BS-66 & MN601371 \\
\hline 15 & Peninsular zone & Pune (MS) & IARI,Pune-1 & BS-68 & MN601372 \\
\hline 16 & Peninsular zone & Pune (MS) & IARI,Pune-1 & BS-69 & MN601373 \\
\hline 17 & Peninsular zone & Dharwad (KN) & Dharwad-1 & BS-72 & MN601374 \\
\hline 18 & $\begin{array}{l}\text { Southern Hill } \\
\text { Zone }\end{array}$ & $\begin{array}{l}\text { Wellington, Tamil } \\
\text { nadu }\end{array}$ & $\begin{array}{l}\text { Wellington } \\
\text { (Nilgiri-2) }\end{array}$ & BS-75 & MN601375 \\
\hline
\end{tabular}




\begin{tabular}{|c|c|c|c|c|c|}
\hline S.No & $\begin{array}{l}\text { Agroclimatic } \\
\text { zone }\end{array}$ & Location/state & Centre name & $\begin{array}{l}\text { Designated } \\
\text { name of isolate }\end{array}$ & $\begin{array}{l}\text { Accession } \\
\text { no. }\end{array}$ \\
\hline 19 & $\begin{array}{l}\text { Southern Hill } \\
\text { Zone }\end{array}$ & $\begin{array}{l}\text { Wellington, Tamil } \\
\text { nadu }\end{array}$ & K8 & BS-88 & MN601376 \\
\hline 20 & $\begin{array}{l}\text { Southern Hill } \\
\text { Zone }\end{array}$ & $\begin{array}{l}\text { Wellington, Tamil } \\
\text { nadu }\end{array}$ & $11 \mathrm{~K}-7$ & BS-91 & MN601377 \\
\hline 21 & $\begin{array}{l}\text { Southern Hill } \\
\text { Zone }\end{array}$ & $\begin{array}{l}\text { Wellington, Tamil } \\
\text { nadu }\end{array}$ & $\mathrm{R}-3$ & BS-94 & MN601378 \\
\hline 22 & $\begin{array}{l}\text { North Eastern } \\
\text { Plains Zone }\end{array}$ & $\begin{array}{l}\text { Varanasi, Uttar } \\
\text { pradesh }\end{array}$ & $\mathrm{BHU}$ & BS-112 & MN601379 \\
\hline 23 & $\begin{array}{l}\text { North Eastern } \\
\text { Plains Zone }\end{array}$ & $\begin{array}{l}\text { Varanasi, Uttar } \\
\text { pradesh }\end{array}$ & & BS-124 & MN601380 \\
\hline 24 & $\begin{array}{l}\text { North Western } \\
\text { plains zone }\end{array}$ & New Delhi & IARI & BS-125 & MN601381 \\
\hline 25 & $\begin{array}{l}\text { North Western } \\
\text { plains zone }\end{array}$ & New Delhi & IARI & BS-126 & MN601382 \\
\hline 26 & $\begin{array}{l}\text { North Western } \\
\text { plains zone }\end{array}$ & New Delhi & IARI & BS-127 & MN601383 \\
\hline 27 & $\begin{array}{l}\text { North Western } \\
\text { plains zone }\end{array}$ & New Delhi & IARI & BS-128 & MN601384 \\
\hline 28 & $\begin{array}{l}\text { North Eastern } \\
\text { Plains Zone }\end{array}$ & $\begin{array}{l}\text { Masodha, Uttar } \\
\text { pradesh }\end{array}$ & Masodha & BS-129 & MN601385 \\
\hline 29 & $\begin{array}{l}\text { North Eastern } \\
\text { Plains Zone }\end{array}$ & $\begin{array}{l}\text { Kanpur, Uttar } \\
\text { pradesh }\end{array}$ & Kanpur & BS-130 & MN601386 \\
\hline 30 & $\begin{array}{l}\text { North Western } \\
\text { plains zone }\end{array}$ & New Delhi & IARI & BS-131 & MN601387 \\
\hline 31 & $\begin{array}{l}\text { North Western } \\
\text { plains zone }\end{array}$ & Karnal (HR) & & BS-132 & MN601388 \\
\hline 32 & $\begin{array}{l}\text { Southern Hill } \\
\text { Zone }\end{array}$ & $\begin{array}{l}\text { Wellington, Tamil } \\
\text { nadu }\end{array}$ & & BS-133 & MN601389 \\
\hline 33 & $\begin{array}{l}\text { North Western } \\
\text { plains zone }\end{array}$ & New Delhi & IARI & BS-134 & MN601390 \\
\hline 34 & $\begin{array}{l}\text { Southern Hill } \\
\text { Zone }\end{array}$ & $\begin{array}{l}\text { Wellington, Tamil } \\
\text { nadu }\end{array}$ & & BS-135 & MN601391 \\
\hline 35 & $\begin{array}{l}\text { North Western } \\
\text { plains zone }\end{array}$ & New Delhi & IARI & BS-136 & MN601392 \\
\hline 36 & $\begin{array}{l}\text { North Western } \\
\text { plains zone }\end{array}$ & New Delhi & IARI & BS-137 & MN601393 \\
\hline
\end{tabular}




\begin{tabular}{|clllll|}
\hline S.No & $\begin{array}{l}\text { Agroclimatic } \\
\text { zone }\end{array}$ & Location/state & Centre name & $\begin{array}{l}\text { Designated } \\
\text { name of isolate }\end{array}$ & $\begin{array}{l}\text { Accession } \\
\text { no. }\end{array}$ \\
\hline 37 & $\begin{array}{l}\text { Southern Hill } \\
\text { Zone }\end{array}$ & $\begin{array}{l}\text { Wellington, Tamil } \\
\text { nadu }\end{array}$ & BS-138 & MN601394 \\
\hline 38 & $\begin{array}{l}\text { North Western } \\
\text { plains zone }\end{array}$ & New Delhi & IARI & BS-139 & MN601395 \\
\hline 39 & $\begin{array}{l}\text { North Western } \\
\text { plains zone }\end{array}$ & New Delhi & IARI & BS-140 & MN601396 \\
\hline
\end{tabular}

Phylogenetic relationship of ToxA gene amongst B. sorokiniana (RCTM00000000), Pyrenophora tritici repentis (MH017419.1), Parastagonospora nodorum (CP022834) and Phaeosphaeria avenaria (JX997418) was concluded using the Neighbor-Joining method in MEGA X (Fig. 8b). The nucleotide sequences of B. sorokiniana ToxA from India (BSToxA) and Australia (AusBSToxA1 and AusBSToxA7) aligned to Pyrenophora tritici repentis (ptr_ToxA) and Parastagonospora nodorum (Sn4_ToxA). All the isolates revealed $100 \%$ homology with Pyrenophora tritici repentis sequence and differing by a single nucleotide from one of the two BSTOxA haplotype identified in Australia (Fig. 9).

\section{ToxA - Tsn1 gene relationship in wheat genotypes}

In the host, the presence of $\operatorname{Tsn} 1$ (xfcp623), a sensitivity gene; helps a ToxA positive pathogen to cause more severe necrotic lesions on wheat genotypes. To predict allelic status at Tsn 1 (400bp amplicon) locus using PCR amplification, thirteen genotypes of wheat were screened; from which 5 wheat genotypes (WH 542, WL 711, HD 29, PBW 343 and Agra local) (38.4\%) were found to be Tsn1 positive, whereas remaining 8 lacked Tsn 1 and instead carry $\operatorname{tsn} 1$ (Fig. 10a). Further, pathogenicity assay of $B$. sorokiniana (BS112) was tested on these thirteen wheat genotypes to identify correlation between Tsn1 (presence or absence) and necrotic lesions formation. Average disease index was calculated on the basis of number and length of lesions on the leaf of different wheat genotypes (Fig. 10b). Genotypes viz. WH 542, WL 711, HD 29, PBW 343 and Agra local showed severe necrotic lesions on leaves when inoculated with $B$. sorokiniana while Tsn 1 negative wheat genotype showed no necrotic lesion formation. This confirmed that ToxA has susceptible reaction phenotype on wheat genotypes harboring Tsn1 gene [Additional file 8: Fig. S1].

\section{Relative expression analysis ToxA gene under in vitro and in planta conditions}

To evaluate host gene expression during fungal infection, relative qPCR with an EFN-1 alpha gene as internal control was performed to determine time-dependent effect of ToxA on wheat genotypes. In vitro expression analysis of ToxA gene in B. sorokiniana isolate (BS112) collected at different time intervals, using qPCR revealed maximum upregulation ( $14.67 \mathrm{fold}$ ) at 1 st day after inoculation (DAl), followed by 2nd DAl (11.83 fold), then gradually expression decreased at 3, 4 and 5 DAl in minimal basal medium 
(Fig. 11a). In planta expression analysis via inoculated leaf collected at different time intervals from two genotypes was performed using qPCR. The maximum expression (7.89 fold) was observed at 5th DAl in susceptible cultivar (Agra local), while minimum expression ( 0.048 fold) was found in resistant cultivar (Chiriya 7) at 5th DAl (Fig. 11b).

\section{Discussion}

Wheat is the most vital food-grain in the Northern and North-western parts of India. After China, India is the second chief producer of wheat in the world and accounts for 8.7 per cent of the world's total production of wheat [23]. It is rich in proteins, carbohydrates and vitamins and provides balanced food. High yield loss in wheat is mainly due to many fungal diseases like wheat rusts, spot blotch, head blight etc. Over the next several decades, due to predicted high global population growth rate, it would be a challenge to meet this rocketing demand of wheat. Management of fungal diseases and development of resistant genotypes of wheat is the key component to meet this challenge [24]. Fungal disease management and to understand the zestful nature of genome of fungal pathogen, whole genome sequencing is of great significance. Genome sequencing of fungal pathogens show extensive variations in genome structure, its composition between species and also between isolates of same species. Genomic sequencing is antecedent for many strategies and alternatives for plant defense reactions against fungal pathogens [25].

Using next generation sequencing technology we have produced a draft genome of $B$. sorokiniana and a total sequence assembly size of $35.64 \mathrm{Mb}$ was predicted [21], which is very similar to $B$. sorokiniana isolate ND90Pr $(34.41 \mathrm{Mb})$ and Shoemaker $(34.33 \mathrm{Mb})$. The genome size of $B$. sorokiniana is notably larger than other species of Bipolaris like B. maydis (32.93 Mb), B. victorae (32.83 Mb), B. zeicola (31.26 $\mathrm{Mb})$, B. oryzae (31.51 Mb) and B. papendorfii (33.4 Mb).

In this approach, pathogen host database systematically complies pathogenicity genes involved in pathogen host interactions. Disrupted genes was also reflected by PHI database which reveals functional redundancy in fungi. Endopolygalacturonases (disruption by a multigene family in $B$. sorokiniana), a plant cell wall degrading enzymes did not affect virulence because other bare type enzymes are reserved to degrade plant cell wall. To better understand gene functions, 2,788 protein coding genes were assigned to different categories. The top categories included transmembrane transport, carbohydrate metabolism, ATP binding etc. which is mainly involved in carbohydrate mechanism such as gluconeogenesis, glycolysis and citric acid cycle (TCA cycle) [26]. This mechanism can facilitate for the use of various substrates of $B$. sorokiniana exposed to various carbohydrate sources in the environment.

Further, study revealed 138 proteins for ankyrin repeat in Pfam domain, which is highly involved in diverse set of cellular functions. Four Ankyrin repeats were present in ToxE, which is responsible for the expression of Tox2 gene present in Bipolaris zeicola (highly virulent on maize genotypes) [27]. 
To penetrate the rigid barriers of plant cell wall, many types of CAZymes (Carbohydrate active enzymes) were produced by fungi. To identify genes responsible for CAZymes, the $B$. sorokiniana genome was mapped to CAZy database. From total CAZymes, 45 glycoside hydrolases $(\mathrm{GH})$ were identified. The number of GH family in other Bipolaris species is also reported higher compared to other CAZymes. Interestingly, the $B$. sorokiniana genome contains a lesser number of $\mathrm{GH}$ family (45) compared with that of the reported Bipolaris species as Bipolaris maydis has 276 families. Our findings revealed that $B$. sorokiniana has 6 carbohydrate esterase (CE) family. The highest number of $\mathrm{CE}_{5}$ (5 copies) and $\mathrm{CE}_{1}$ (3 copies) indicated that $B$. sorokiniana produces many plant degrading enzymes containing cutinase and carboxylesterase activity. From 18 carbohydrate binding modules (CBM) family $\mathrm{CBM}_{1}$ and $\mathrm{CBM}_{18}$ has the highest number of genes indicating chitin binding activity. High number of CBM and GH family may have the ability to degrade lignocellulose (main structural component of plant) collectively [28]. This indicate that $B$. sorokiniana has wide variety of CAZymes which is involved in the deprivation of plant cell wall complex carbohydrates.

In this study, we reported the functional identification of ToxA gene in different Indian populations of $B$. sorokiniana. ToxA gene in a global population dataset was found to be drastically different depending upon the area from which population was sampled. Earlier, for Australian populations of $P$. nodorum and P. tritici-repentis, ToxA was present in all the tested isolates [29, 30]. Recently, Navathe et al. [20] reported $70 \%$ of ToxA positive isolates in tested Indian population of $B$. sorokiniana, whereas our results revealed that ToxA gene existed (100\%) in all the Indian isolates of $B$. sorokiniana taken for the study. In the present study, the gene ToX $A$ was PCR amplified in all the 39 isolates of $B$. sorokiniana and the length of the amplicon in all the isolates was uniform (535bp). The sequencing data suggested that, there is a high degree of similarity of ToxA gene present in B. sorokiniana, Pyrenophora tritici and Phaeosphaeria species. The similarity between these three species can be best illustrated by horizontal gene transfer [13]. The horizontal gene transfer may be due to hybridization between the various fungal species [16]. The exact sequence match of $B$. sorokiniana (BS112) and other two species reveals a recent global migration of these strains.

The expression of ToxA gene investigated using qPCR, measure the level of $B$. sorokiniana in leaf tissue at different time intervals displaying disease symptoms. Gene expression levels were compared by $\mathrm{C}_{\mathrm{T}}$ (threshold) values for each runner gene. The stability of gene expression was reflected through coefficient of variation of $\mathrm{C}_{\mathrm{T}}$ values, wherein higher the $\mathrm{C}_{\mathrm{T}}$ values lower will be the gene expression levels and vice versa. Pathogenicity assay and PCR amplification confirmed that the isolate carrying ToxA caused severe necrotic lesions on wheat genotypes having the sensitivity gene Tsn1. In contrast, it caused less or no lesions to wheat genotypes lacking Tsn1. Quantitative gene expression analysis and pathogenicity assay revealed that necrotic symptoms observed on Agra local genotype leaves was due to high expression of ToxA gene, which gradually increased and caused leaf abscission, whereas, on chiriya 7 its effect is reverse. Tsn 1 is the part of complex network of resistance / susceptibility to spot blotch. According to Navathe et al., ToxA-Tsn 1 have gene to gene relationship; similarly our study also confirms ToxA positive isolates showing more severe necrosis on wheat genotype harboring Tsn 1 gene [20]. Recently, Lei et al. 
also confirmed the ToxA-Tsn 1 relationship through culture filtrate infiltration method. However, the appearance of necrosis on the wheat leaf is not only induced by ToxA but can be through some other toxins present in culture filtrate or crude extract [31]. Study of ToxA-Tsn1 interaction is very useful for breeding program, which are highly prone to spot blotch. Wheat breeders may avoid the genotype with $T s n 1$ allele and retain genotypes with tsn 1 allele.

\section{Conclusions}

In this study, detailed analysis of genome of $B$. sorokiniana (BS112) was conducted, which lead to the identification of unique SSRs, protein domains, secretory proteins, establishment of phylogenetic relationship among different Bipolaris species and understanding the genes involved in host-pathogen interactions at molecular level. This study, further stated the ToxA-Tsn 1 interaction in Indian wheat genotypes and confirmed that spot blotch is more severe in Tsn1 positive wheat genotypes.

\section{Methods}

\section{Fungal- collection, isolation and DNA extraction}

Wheat infected leaves were collected from different region of India. For the isolation of the pathogen, infected leaves were surface sterilized and necrotic lesions were cut into smaller fragments. These fragments were washed with $0.1 \%$ sodium hypo chlorite $\left(\mathrm{NaOCl}_{2}\right)$ solution, followed by washing with water 2 times. To induce sporulation, these fragments were placed on PDA (potato dextrose agar) under a 12-h photoperiod at room temperature (RT). Several single spores from each of the PDA plates transferred to another PDA plates and allow to grow at $25^{\circ} \mathrm{C}$. Meanwhile, these spores are observed in microscope and fungus was identified based on conidia and its morphology [32].

Thirty nine isolates of $B$. sorokiniana were established from infected wheat leaf samples collected from different regions of India. These cultures were grown in potato dextrose broth (PDB) and incubated at $25^{\circ} \mathrm{C}$ with periodical shaking. After 25 days the mycelial mats $(0.2 \mathrm{~g})$ from each isolates was harvested aseptically and snap frozen in liquid nitrogen. Frozen mycelia were subjected to DNA extraction using CTAB method [33]. Then, the quantity and quality were assessed using a Qubit $\circledast 2.0$ Fluorometer (Thermo Fisher Scientific, Wilmington, USA) and agarose gel electrophoresis respectively. Genomic DNA of BS112 (ITS NCBI accession- KU201275) was sent to Genotypic Technology (P) Ltd. for genome sequencing using hybrid genome assembly through Ilumina, Nano pore and Ion-torrent platforms.

\section{Genome sequencing and hybrid assembly}

The genome of $B$. sorokiniana was sequenced by using Illumina Hiseq, Oxford Nanopore sequencing and lon-Torrent platform technologies. The fungal hybrid assembly is the main aim of the project. The Illumina reads were pre-processed using Trim-galore [34], and Nano pore fast5 data were base called 
using Albacore [35]. Hybrid genome assembly was created using these three types of sequenced reads. Kmer analysis will not require in hybrid assembly because the internal long read algorithm was based on overlap layout consensus (OLC). For hybrid assembly MaSuRCA tool [36] is used and output of the hybrid assembly of genome is $35.64 \mathrm{Mb}$. Later using pyScaf, the contigs were processed [37]. The paired end library data was generated using Illumina HiSeq platform.

\section{Gene prediction, annotation and pathway analysis}

Genes was predicted in the genome of $B$. sorokiniana using AUGUSTUS annotation tool [38]. A total of 10,460 genes were projected with an average gene length of $435-545 \mathrm{bp}$ on the basis of B. sorokiniana ND90Pr as reference genome. Maximum gene length of 8,506 and minimum gene length of 35 was identified.

Functional annotation of genes were performed using BLASTx tool [39]. The predicted proteins were similarity searched against fungal protein database using ncbi-blast-2.2.29+ blastp program with an evalue of $1 \mathrm{e}-5$ for gene ontology and annotation. Around $98 \%$ of predicted genes were annotated against the protein database. The proteins were annotated against all Viridi plantae kingdom protein sequences (from Uniprot Protein Database). Further analysis, those proteins with more than $30 \%$ identity as cut off were taken. The gene annotation was done by fungal hybrid assembly in biological, chemical and molecular functions. The pathway analysis of the predicted genes was performed through KEGG database [40].

\section{Phylogenetic analysis of $B$. sorokiniana genomes}

Based on whole-genome alignment, Progressive Mauve version 20150213 build 0 with default parameters was used to execute phylogenetic analysis [41]. Five species of Bipolaris namely $B$. sorokiniana/ Cochliobolus sativus, Bipolaris maydis/ Cochliobolus heterostrophus, $B$. oryzael Cochliobolus miyabeanus, B. zeicola/ Cochliobolus carbonum and B. victoriae/ Cochliobolus victoriae, two isolates of $B$. sorokiniana namely B. sorokiniana/ Cochliobolus sativus (ND90Pr), $B$. sorokiniana/ Cochliobolus sativus query sample (BS112) and one isolate of Pyrenophora triticirepentis (outgroup) were taken for the multiple genome alignment. Through neighbor joining tree, comparative analysis was performed on all six genomes. The guide tree was an output of multiple sequence alignment in Mauve. The phylogenetic trees were constructed using the guide tree in phylogeny.

\section{Comparative genome annotation of orthologous gene families}

The orthologous gene families among the Bipolaris species GCA_000527765.1, GCA_000523455.1, GCA_000523435.1 were identified using OrthoVenn. Comparison among these species revealed 8674 


\section{SNP (Single Nucleotide Polymorphism) and SSR (Simple Sequence Repeat) analysis}

SNP prediction was processed using snpEff tool with Illumina Hiseq data [42]. Alignment was done using minimap2 [43] and variant detection was done using Sam-tools [44]. Through MicroSatellite identification tool (MISA) tool with default parameters simple sequence repeats were identified [45].

\section{Protein family classification}

Protein domain analysis was widely done using Pfam database [46]. HMMER 3.0 was used to infer Pfam domains by removing overlapping clans. From derived protein sequences, in total 12082 proteins domain were found to be associated.

\section{Secretome analysis}

In the current study, secretome prediction of $B$. sorokiniana genome was analyzed using SignalP v4.1 in combination with TargetP v1.1 for all possible secreted proteins. These secreted proteins then examined for transmembrane (TM) spanning regions using TMHMM (TMHMM v2.0; http://www.cbs.dtu.dk/cgibin/nph-sw_request? tmhmm). The proteins located in the predicted $\mathrm{N}$-terminal signal peptide is retained as 0 or 1 transmembrane region. Big-PI (http://mendel.imp.ac.at/ gpi/cgi-bin/gpi_pred_fungi.cgi) is used to predict GPI- anchor proteins. Localization of the remaining proteins was predicted using ProtComp by LocDB and PotLocDB databases (ProtComp v8.0; http://www.softberry.com). After secretion, location of proteins was estimated using WoLFPSORT, analysis done by "run WolfPsort summary fungi" in the WoLFPSORT V0.2 package (70\% specificity and sensitivity) [47]. Blast2GO [48] (http://www.blast2go.com/b2glaunch) was used to explore whether any additional gene annotation existed from protein set within the predicted refined secretome. From refined secretome, genes were identified which was further classified into six carbohydrate-active enzymes (CAZy) classes; polysaccharide lyases $(\mathrm{PL})$, glycoside hydrolases $(\mathrm{GH})$, carbohydrate esterases (CE), carbohydrate binding modules (CBM), auxiliary activities (AA) and glcosyl transferases (GT) using CAZy database (http://www.cazy.org/).

\section{Primer designing and amplification of ToxA gene}

ToxA gene was extracted from a genomic region of Pyrenophora tritici-repentis isolate PTR-01, complete coding sequence (Accession number- MH017419). The sequence specific primers were designed using Integrated DNA Technologies (IDT) primer designing tool. Amplification of ToxA gene from genomic DNA 
was ensured using primer pair ToxA BS F 5'TCATGCGTTCTATCCTCGTA3' and ToxA BS R $5^{\prime}$ CTAATTTTCTAGCTGCATTCTCCA3'. The PCR condition include initial denaturation at $95^{\circ} \mathrm{C}$ for $5 \mathrm{~min}$; followed by 39 cycles of amplification, each cycle with the following plan: denaturation at $94^{\circ} \mathrm{C}$ for $30 \mathrm{~s}$, annealing at $52^{\circ} \mathrm{C}$ for $30 \mathrm{~s}$, and extension at $72^{\circ} \mathrm{C}$ for $1 \mathrm{~min}$; followed by final extension at $72^{\circ} \mathrm{C}$ for 10 min. By gel electrophoresis (1.2\%), PCR products were visualized. Amplified product was gel purified, sequenced and analyzed against NCBI database. The amplicon sequencing was outsourced by Eurofins Genomics India Pvt. Ltd. (Bengaluru, India). The sequences obtained were aligned using BioEdit Sequence Alignment Editor. Phylogenetic analysis was done using Molecular Evolutionary Genetics Analysis (MEGA-X), amongst plant pathogen viz. B. sorokiniana, Pyrenophora tritici repentis, Parastagonospora nodorum, phaeosphaeria avenaria species was inferred using the Neighbor-Joining method. In this study, the sequences of ToxA used were deposited in NCBI GenBank.

\section{Tsn1 allelic status in Indian wheat genotype and its pathogenicity assay}

ToxA, a necrotropic effector was mapped to wheat chromosome arm $5 \mathrm{BL}$, reveals the inverse gene to gene relationship with a sensitivity gene called as Tsn1. B. sorokiniana isolate carrying ToxA gene causes severe necrotic lesions on wheat genotypes harboring $T s n 1$ sensitivity gene. Thirteen wheat genotypes were taken from different regions of India which includes WH 542, WL 711, Agra Local, Suzoe, HD 29, PBW 343, HD 3086, Chiriya 7, HD 30, Milan, HD 2329, Ning 8139, HD 2967. These genotypes are further classified based on presence or absence of Tsn1. To test ToxA-Tsn 1 relationship, the collected wheat genotypes was grown in a moist chamber maintaining the temperature of approx. $25^{\circ} \mathrm{C}$; at two leaf stage BS112 (positive for ToxA gene) was inoculated on leaves. Genomic DNA was isolated from above mentioned wheat genotypes using CTAB method. PCR amplification was carried out using dominant marker Xfcp623 (F 5'CTATTCGTAATCGTGCCTTCCG3' and R 5'CCTTCTCTCTCACCGCTATCTCATC3') procured from intron five of $T s n 1$ gene at annealing temperature of $57^{\circ} \mathrm{C}$. PCR results, amplicon presence infer $\operatorname{Tsn} 1$ (presence) and its absence infer tsn1 (absence).

Pathogenicity assay were tested on 3 week old plant of thirteen different wheat genotypes as mentioned above. The inocula was prepared from BS112, cultured in sorghum grain under aseptic conditions and after 25 days, the inoculum was crushed in water and filter through muslin cloth having a spore density of $1 \times 10^{6}$ spores $/ \mathrm{mL}$, for uniform spraying Tween 20 was added to spore suspension and the inoculum was prepared. Plants were kept in poly house in glass chamber were the temperature was maintained at $25^{\circ} \mathrm{C}$, followed by $>80 \%$ of relative humidity. Spore suspension of BS112 was sprayed on the flag leaf of all genotypes in four plant each. Photographs were taken at 4 days of post-inoculation and disease severity (\%) was calculated as per the scale; $0=$ free of spots; $1=$ up to $5 \%$ leaf area covered with necrotic spots; $2=6-20 \%$ of the leaf area covered; $3=21-40 \%$ of the leaf area covered; $4=41-60 \%$ of the leaf area covered; $5=$ spots inclusion more than $60 \%$ of the leaf area tangled. 
Average Disease Index (ADI) was calculated using the formula: ADI = ((sum of rating of each leave) / (total leaf $* 5) / 100$ ). ADI was converted into disease responses viz. $0=$ No infection; $0-10=$ resistant response $(R) ; 10.1-20=$ moderately resistance $(M R) ; 20.1-30=$ moderately susceptible (MS); 30.1- 50= susceptible(S); and more than $50=$ highly susceptible (HS) $[49,50]$.

\section{Expression analysis of ToxA under in vitro and in planta conditions}

For in planta gene expression analysis using qPCR, BS112 (most aggressive isolate) was inoculated to highly resistant cultivar (Chiriya 7) and susceptible cultivar (Agra local) of wheat. The pots were kept in moist chamber maintaining the temperature of approx. $25^{\circ} \mathrm{C}$. After inoculation of BS112 (as described earlier), leaf samples with disease symptoms (photographs were taken) were collected at $1^{\text {st }}, 2^{\text {nd }}, 3^{\text {rd }}, 4^{\text {th }}$ and $5^{\text {th }}$ day, kept in aluminum foil and immediately frozen in liquid nitrogen. In vitro expression analysis was also done using qPCR of ToxA gene in B. sorokiniana isolate BS112 grown in potato dextrose broth (PDB); harvested at same time points as mentioned above.

Total RNA was isolated from leaf samples inoculated with BS112 and fungal mycelia (BS112) using Trizol (Invitrogen) reagent method as per the manufacturer' guidelines. RNA quantification was done using nanodrop. First strand cDNA was synthesized using Revertaid cDNA synthesis kit (Thermo fisher scientific, Wilmington, USA) as per the manufacturer' guidelines and was stored at $-20^{\circ} \mathrm{C}$ for further use.

Quantitative gene expression was performed using primer pair ToxA_RP_FTGCGTTCTATCCTCGTACTTC and TOXA_RP_RGTGATTGACATGCAGCTTCC (designed using Integrated DNA Technologies (IDT) primer designing tool) to amplify the ToxA gene. A housekeeping EFN-1 alpha gene (EFN-

1FCTTCTCGCCTACACCCTTG and EFN-1RCCTTCTCCCAACCCTTGTAC) was also used. The designed primers were synthesized (Eurofins Genomics India Pvt. Ltd., Bengaluru, Karnataka, India).

The quantitative PCR was performed on 48- well plates mini opticon real time PCR system (Biorad, Hercules, California, USA) with the following conditions: an initial activation step at $95^{\circ} \mathrm{C}$ for $7 \mathrm{~min}$; followed by 35 cycles of denaturation at $95^{\circ} \mathrm{C}$ for $15 \mathrm{~s}$, annealing at $53^{\circ} \mathrm{C}$ for $30 \mathrm{~s}$, and extension at 72 ${ }^{\circ} \mathrm{C}$ for $30 \mathrm{~s}$; melt curve analysis of the PCR product was carried out at $72{ }^{\circ} \mathrm{C}$ for $1 \mathrm{~min}$ and ramped from 75 to $95^{\circ} \mathrm{C}$ with a rise by $1^{\circ} \mathrm{C}$ every $5 \mathrm{~s}$. qPCR was done using SYBR Green PCR master mix (Fermentas) which includes $10 \mu \mathrm{l}$ of SYBR Green PCR master mix , 10nM of the appropriate primer (both EFN-1 alpha and ToxA) and 100ng of template cDNA with a total of $20 \mu \mathrm{l}$ reaction. Each experiment was carried out in triplicates with two technical replicates, relative gene expressions were calculated in terms of fold changes using the ${ }^{\Delta \triangle} \mathrm{Ct}$ method [51].

\section{Abbreviations}


SSR: Simple Sequence Repeat; GO: Gene ontology; DAl: Days after inoculation; SNP: Single nucleotide polymorphism; GH: Glycoside hydrolases; CBM: Carbohydrate Binding Modules; CE: Carbohydrate esterase; PL: Polysaccharide lyases; AA: Auxiliary activities; GT: Glcosyl transferases; qPCR: quantitative real time PCR; TCA: Citric acid cycle; CaZymes: Carbohydrate active enzymes; OLC: Overlap layout consensus; ADI: Average disease index; R: resistance; MR: Moderately resistance; HR: Highly resistance; S: susceptible; HS: Highly susceptible; MS: Moderately susceptible; IDT: Integrated DNA technologies; SNB: Septoria nodorum blotch

\section{Declarations}

\section{Acknowledgements}

Authors are highly thankful to the ICAR-Consortium Research Platform (CRP) on Genomics (ICAR-G/CRPGenomics/2015-2720/IARI-12-151) for funding this work. The funders had no role in study design, data collection and interpretation, or the decision to submit the work for publication. We are very thankful to the Director and Joint Director (Research) of the ICAR-Indian Agricultural Research Institute, New Delhi, the Head, Division of Plant Pathology, ICAR-IARI, New Delhi, and the Director of ICAR-NIPB, New Delhi for providing facilities.

\section{Funding}

This work is financially supported by the Indian Council of Agricultural Research-Consortium Research Project (CRP) on Genomics (ICAR-G/CRP-Genomics/2015-2720).

\section{Authors' contributions}

RA and SA wrote the manuscript; RA, BB, MG and MS contributed corrections and suggestions; AR and SSa performed the bioinformatics analysis; RA, SA and PJ analyzed the data and conducted the wet lab experiments; RA, SSh and MG conceived and designed the experiment. All the authors read and approved the final manuscript.

\section{Availability of data and materials}

This whole-genome sequencing project has been deposited in DDBJ/ENA/GenBank under the accession number RCTM00000000, BioProject number PRJNA489551, and BioSample identification (ID) SAMN09901300. The version described in this paper is the first version (GenBank accession number RCTM01000000). The raw sequencing data of all the three platforms were deposited in the DDBJ SRA database under the accession numbers SRX6673825 (Ion Torrent), SRX6673824 (Illumina HiSeq), and SRX6100476 (Oxford Nanopore). 


\section{Ethics declarations}

\section{Ethics approval and consent to participate}

Not applicable.

\section{Consent for publication}

Not applicable.

\section{Competing interests}

The authors declare that they have no competing interests.

\section{Author details}

ICAR- Indian Agriculture Research Institute, Pusa campus, New Delhi.

ICAR- Centre for Agricultural Bioinformatics, IASRI, New Delhi

Indian Council of Agricultural Research, ICAR, New Delhi

\section{References}

1. Zillinsky F. In: Common diseases of small grain cereals, a guide to identification. CIMMYT, Mexico, DF; 1983. pp141.

2. Wiese MV. Compendium of wheat diseases. In: Duveiller E, Dubin HJ, Reeves J, McNab A (eds) Proc. Int. Workshop Helminthosporium Disease of Wheat: Spot Blotch and Tan Spot. 9-14 Feb. 1997, CIMMYT, El Batan, Mexico, DF. 1998;pp 114-118.

3. Van Ginkel M, Rajaram S. Breeding for durable resistance to diseases in wheat: an additional perspective. In: Jacobes T, Parlevliet JE (eds) Durability of disease resistance. Kluwer Academic Publishers, Dordrecht, Netherlands. 1993; pp259-272.

4. Nagarajan S, Kumar J. Foliar blights of wheat in India: germplasm improvement and future challenges for sustainable high yielding wheat production. In: Duveiller E, Dubin HJ, Reeves J and McNab A (eds) Proc. Int. Workshop Helminthosporium Diseases of Wheat: Spot Blotch and Tan Spot, 9-14 February 1997, CIMMYT, El Batan, Mexico, DF. 1998;pp 52-58 
5. Alam KB, Banu SP, Shaheed MA. The occurrence and significance of spot blotch disease in Bangladesh. In: Duveiller E, Dubin HJ, Reeves J and McNab A (eds) Proc. Int. Workshop on Helminthosporium Disease of Wheat: Spot Blotch and Tan Spot, CIMMYT, El Batan, Mexico. 9-14 February 1997. 1998;pp 63-66

6. Kumar S, Roder MS, Tripathi SB, Kumar S, Chand R, Joshi AK, Kumar U. Mendelization and fine mapping of a bread wheat spot blotch disease resistance QTL. Mol. Breed. 2015;35:218.

7. Chaurasia S, Chand R, Joshi AK. Relative dominance of Alternaria triticina Pras. et Prab and Bipolaris sorokiniana (Sacc.) Shoemaker, in different growth stages of wheat (T. aestivum L.). J. Plant Dis. Prot. 2000;107:176-181.

8. Maraite H, Zinno TDI, Longree H, Daumerie V, Dueveiller E. Fungi association with foliar blight of wheat areas. In: Duveiller E, Dubin HJ, Reeves J, McNab A (eds.), Helminthosophism Diseases of Wheat: Spot Blotch and Tan Spot. CIMMYT, Mexico. 1998;pp. 293-300.

9. Kumar J, Schafer P, Huckelhoven R, Langen G, Baltruschat H, Stein E, Nagarajan S, Kogel KH. Bipolaris sorokiniana, a cereal pathogen of global concern: cytological and molecular approaches towards better control. Molecular Plant Pathology. 2002;3: 185-195.

10. Aggarwal R, Das S, Jahani M, Singh D. Histopathology of spot blotch disease of wheat caused by Bipolaris sorokiniana (Teleomorph: Cochliobolus sativus). Acta Phytopathologica et Entomologica Hungarica. 2008;43(1):23-30.

11. Gayad SK. Production of symptoms of barley leaf spot disease by cultural filtrates of Helminthosporium sativum. Nature. 1961;191:725-726.

12. Jahani M, Aggarwal R, Gupta S, Sharma S, Dureja P. Purification and characterization of a novel toxin from Bipolaris sorokiniana, causing spot blotch of wheat and analysis of variability in the pathogen. Cereal Research Communications. 2014;42(2): 252-261.

13. Friesen TL, Stukenbrock EH, Liu Z, Meinhardt S, Ling H, Faris JD, Rasmussen JB, Solomon PS, McDonald BA, Oliver RP. Emergence of a new disease as a result of interspecific virulence gene transfer. Nat. Genet. 2006;38:953-956.

14. Stukenbrock EH, McDonald BA. Geographical variation and positive diversifying selection in the hostspecific toxin SnToxA. Mol. Plant Pathol. 2007;8:321-332.

15. Moolhuijzen PM, See PT, Oliver RP, Moffat CS. Genomic distribution of a novel Pyrenophora triticirepentis ToxA insertion element. PLoS ONE. 2018;13(10):e0206586.

16. McDonald MC, Ahren D, Simpfendorfer S, Milgate A, Solomon PS. The discovery of the virulence gene ToxA in the wheat and barley pathogen Bipolaris sorokiniana. Mol Plant Pathol. 2018;19(2):432-439.

17. Friesen TL, Holmes DJ, Bowden RL, Faris JD. ToxA Is Present in the U.S. Bipolaris sorokiniana Population and Is a Significant Virulence Factor on Wheat Harboring Tsn1. Plant Disease. 2018;102(12):2446-2452.

18. Gupta P, Vasistha N, Aggarwal R and Joshi A. Biology of B. sorokiniana (syn. Cochliobolus sativus) in genomics era. Journal of Plant Biochemistry and Biotechnology. 2017;27(10):1007/s13562-017- 
0426-6.

19. Faris JD, Zhang Z, Lu H, et al. A unique wheat disease resistance-like gene governs effector-triggered susceptibility to necrotrophic pathogens. Proc. Natl. Acad. Sci. U S A. 2010;107(30):13544-13549.

20. Navathe S, Yadav PS, Chand R, Mishra VK, Vasistha NK, Meher PK, Joshi AK, and Gupta PK. ToxATsn 1 Interaction for Spot Blotch Susceptibility in Indian Wheat: An Example of Inverse Gene-for-Gene Relationship. Plant Disease. 2020;104(1):71 - 8.

21. Aggarwal R, Sharma S, Singh K, Gurjar MS, Saharan MS, Gupta S, Bashyal BM and Gaikwad K. First Draft Genome Sequence of Wheat Spot Blotch Pathogen Bipolaris sorokiniana BS_112 from India, Obtained Using Hybrid Assembly. Microbiol. Resour. Announc. 2019;8(38):e00308-19.

22. Peterson TN, Brunak S, von HG, Nielsen H. SignalP 4.0: discriminating signal peptides from transmembrane regions. Nature Methods. 2011;8:785-786.

23. Ramadas S, Kiran Kuma, TM, Pratap Singh G. Wheat Production in India: Trends and Prospects. Recent Advances in Grain Crops Research. 2020; doi:10.5772/intechopen.86341.

24. Figueroa M, Hammond-Kosack KE, Solomon PS. A review of wheat diseases-a field perspective. Mol. Plant Pathol. 2018;19(6):1523-1536.

25. Aylward J, Steenkamp ET, Dreyer LL, Roets F, Wingfield BD, Wingfield MJ. A plant pathology perspective of fungal genome sequencing. IMA Fungus. 2017;8(1):1-15.

26. Kuan CS, Yew SM, Toh YF, Chan CL, Ngeow YF, Lee KW, Na SL, Yee WY, Hoh CC, Ng KP. Dissecting the fungal biology of Bipolaris papendorfir: from phylogenetic to comparative genomic analysis. DNA Res. 2015;22(3):219-32.

27. Pedley KF, Walton JD. Regulation of cyclic peptide biosynthesis in a plant pathogenic fungus by a novel transcription factor. Proceedings of the National Academy of Sciences. 2001;98(24):1417414179.

28. Lam MQ, Oates NC, Thevarajoo S, Tokiman L, Goh KM, Mason SJM, Bruce NC, Chong CS. Genomic analysis of a lignocellulose degrading strain from the underexplored genus Meridianimaribacter. Genomics. 2020;112(1).

29. Antoni EA, Rybak K, Tucker MP, Hane JK, Solomon PS, Drenth A, Shankar M, Oliver RP. Ubiquity of ToxA and absence of ToxB in Australian populations of Pyrenophora tritici-repentis. Austral. Plant Pathol. 2010;39:63-68.

30. McDonald MC, Oliver RP, Friesen TL, Brunner PC, McDonald BA. Global diversity and distribution of three necrotrophic effectors in Phaeosphaeria nodorum and related species. New Phytol. 2013;199: 241-251.

31. Wu L, He X, Lozano N, et al. ToxA, a significant virulence factor involved in wheat spot blotch disease, exists in the Mexican population of Bipolaris sorokiniana. Trop. plant pathol. 2020; pp46; doi:10.1007/s40858-020-00391-4.

32. Aggarwal R, Singh VB, Shukla R, Gurjar MS, Gupta S, Sharma TR. URP-based DNA fingerprinting of Bipolaris sorokiniana isolates causing spot blotch of wheat. J. Phytopathol. 2010;158: 210-216. 
33. Murray MG, Thompson WF. Rapid isolation of high molecular weight plant DNA. Nucleic Acids Res. 1980;8(19): 4321-4325.

34. Krueger F. Trim galore. A wrapper tool around Cutadapt and FastQC to consistently apply quality and adapter trimming to FastQ files. 2015.

35. Sahoo N. Sequence Base-calling through Albacore software: A part of the OxfordNanopore Technology (Doctoral dissertation). 2017.

36. Zimin AV, Marçais G, Puiu D, Roberts M, Salzberg SL, Yorke JA. The MaSuRCA genome assembler. Bioinformatics. 2013;29(21):2669-2677.

37. Bryant JM, Baumgarten S, Lorthiois A, Scheidig-Benatar C, Claës A, Scherf A. De Novo Genome Assembly of a Plasmodium falciparum NF54 Clone Using Single- Molecule Real-Time Sequencing. Genome announcements. 2018;6(5):e01479-17.

38. Stanke M, Morgenstern B. AUGUSTUS: a web server for gene prediction in eukaryotes that allows user-defined constraints. Nucleic Acids Res. 2005;W465-7. doi: 10.1093/nar/gki458.

39. Altschul, Stephen F, et al. "Basic local alignment search tool." Journal of molecular biology. 1990;215(3):403-410.

40. Kanehisa M, Furumichi M, Tanabe M, Sato Y, Morishima K. KEGG: new perspectives on genomes, pathways, diseases and drugs. Nucleic Acids Research. 2017;D1(45):353-361.

41. Darling AE, Mau B, Perna NT. progressiveMauve: Multiple Genome Alignment with Gene Gain, Loss and Rearrangement. PLOS ONE. 2010;5(6):e11147.

42. Cingolani P, Platts A, Wang LL, Coon M, Nguyen T, Wang L, Ruden DM. A program for annotating and predicting the effects of single nucleotide polymorphisms, SnpEff: SNPs in the genome of Drosophila melanogaster strain w1118. iso-2;iso-3. Fly. 2012;6(2):80-92.

43. Li H. Minimap2: fast pairwise alignment for long DNA sequences. Bioinformatics. 2018;34:30943100.

44. Li H, Handsaker B, Wysoker A, Fennell T, Ruan J, Homer N, Marth G, Abecasis G and Durbin R. 1000 Genome Project Data Processing Subgroup, The Sequence alignment/map (SAM)format and SAMtools. Bioinformatics. 2009;25(16):2078-9 [19505943].

45. Beier S, Thiel T, Münch T, Scholz U, Mascher M. MISA-web: a web server for microsatellite prediction. Bioinformatics. 2017;15:33(16):2583-2585.

46. Finn RD, Bateman A, Clements J, Coggill P, Eberhardt RY, Eddy SR, Heger A, Hetherington K, Holm L, Mistry J, Sonnhammer EL, Tate J, Punta M. Pfam: the protein families database. Nucleic Acids Res. 2014;42:222-30.

47. Horton P, Park KJ, Obayashi T, Fujita N, Harada H, Collier CJA, Nakai K. WoLF PSORT: protein localization predictor. Nucleic Acids Research. 2007;35(2):85-87.

48. Conesa A, and Götz, S. Blast2GO: A comprehensive suite for functional analysis in plant genomics. International journal of plant genomics. 2008;619832. 
49. Adlakha KL, Wilcoxson HD and Raychaudhury SP. Resistance of wheat to leaf spot caused by Bipolaris sorokiniana. Plant Disease. 1984; 68:320-321.

50. Aggarwal R, Singh VB, Gurjar MS, Gupta S, Srinivas P. Intraspecific variations in Indian isolates of Bipolaris sorokiniana infecting wheat based on morphological, pathogenic and molecular characters. Indian Phytopath. 2009;62(4):449-460.

51. Livak KJ, Thomas S. Analysis of relative gene expression data using real-time quantitative PCR and the 2- ${ }^{\Delta \Delta}$ Ct method. Methods. 2001;25:402-408.

\title{
Figures
}

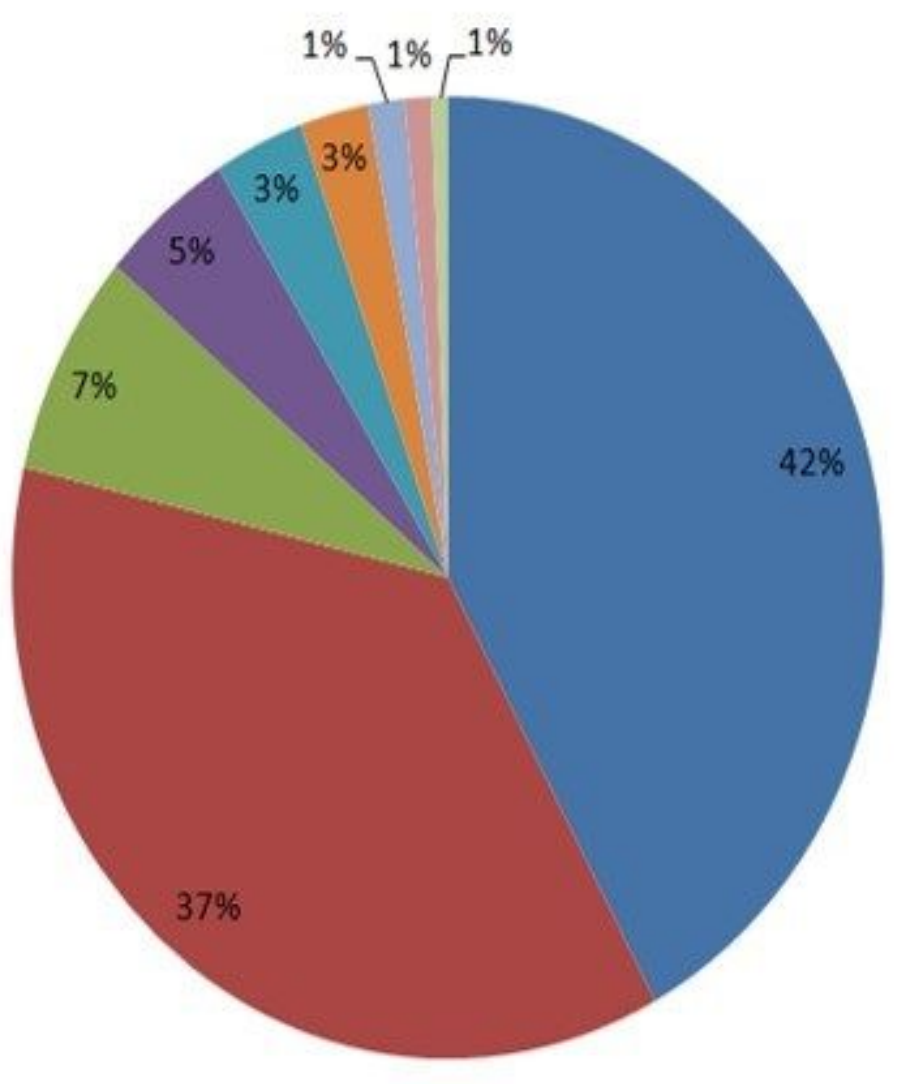

\author{
I reduced_virulence \\ munaffected_pathogenicity \\ = loss_of_pathogenicity \\ In lethal \\ \| unaffected_pathogenicity_reduced \\ _virulence \\ mincreased_virulence_(hypervirulence \\ ) \\ = reduced_virulence__unaffected_pat \\ hogenicity \\ wreduced_virulence_loss_of_pathog \\ enicity \\ = loss_of_pathogenicity_reduced_vir \\ ulence
}

\section{Figure 1}

Whole genome functional annotation of Bipolaris sorokiniana predicted genes using pathogen-host interaction $(\mathrm{PHI})$ database. 


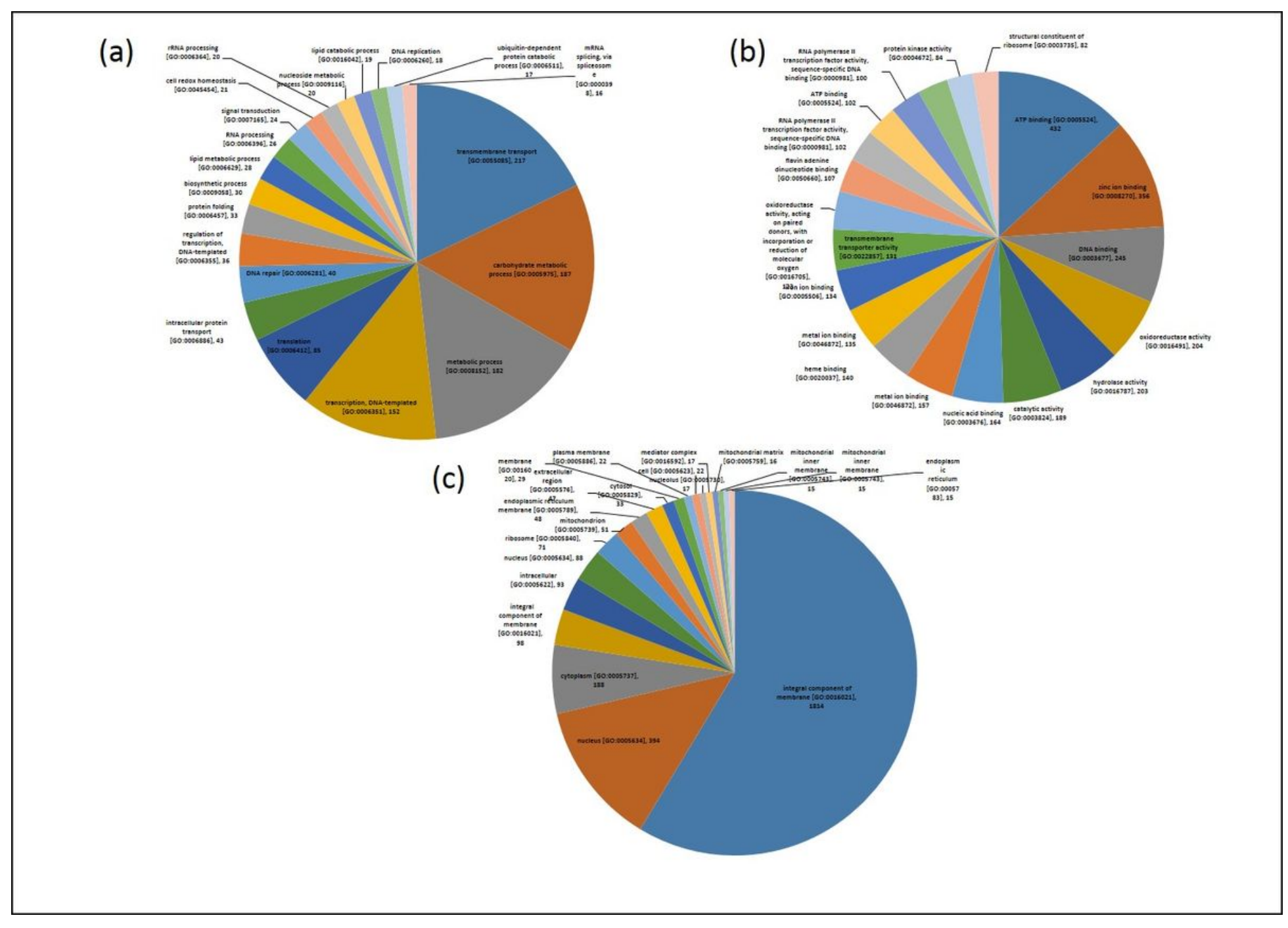

\section{Figure 2}

Gene ontology based functional annotation of genes present in the Bipolaris sorokiniana genome; (a) biological process; (b) molecular function; (c) cellular component. 

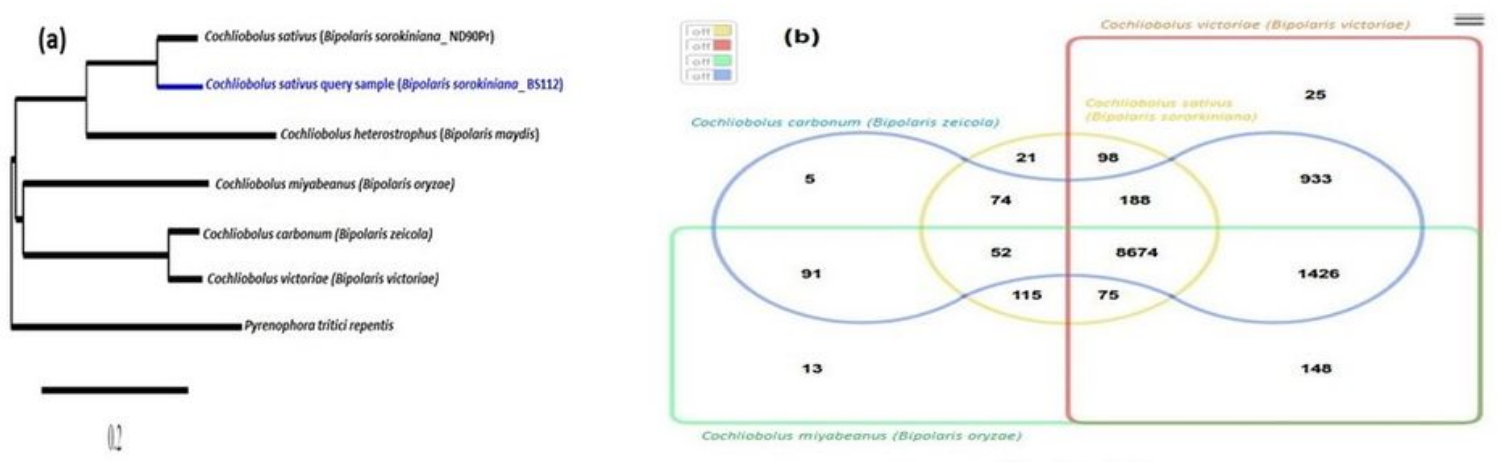

Figure 3

(a) Whole genome phylogenic analysis between different species of Bipolaris and Pyrenophora tritici repentis used as outgroup; (b) Venn diagram showing unique and shared orthologous gene families between Bipolaris species.

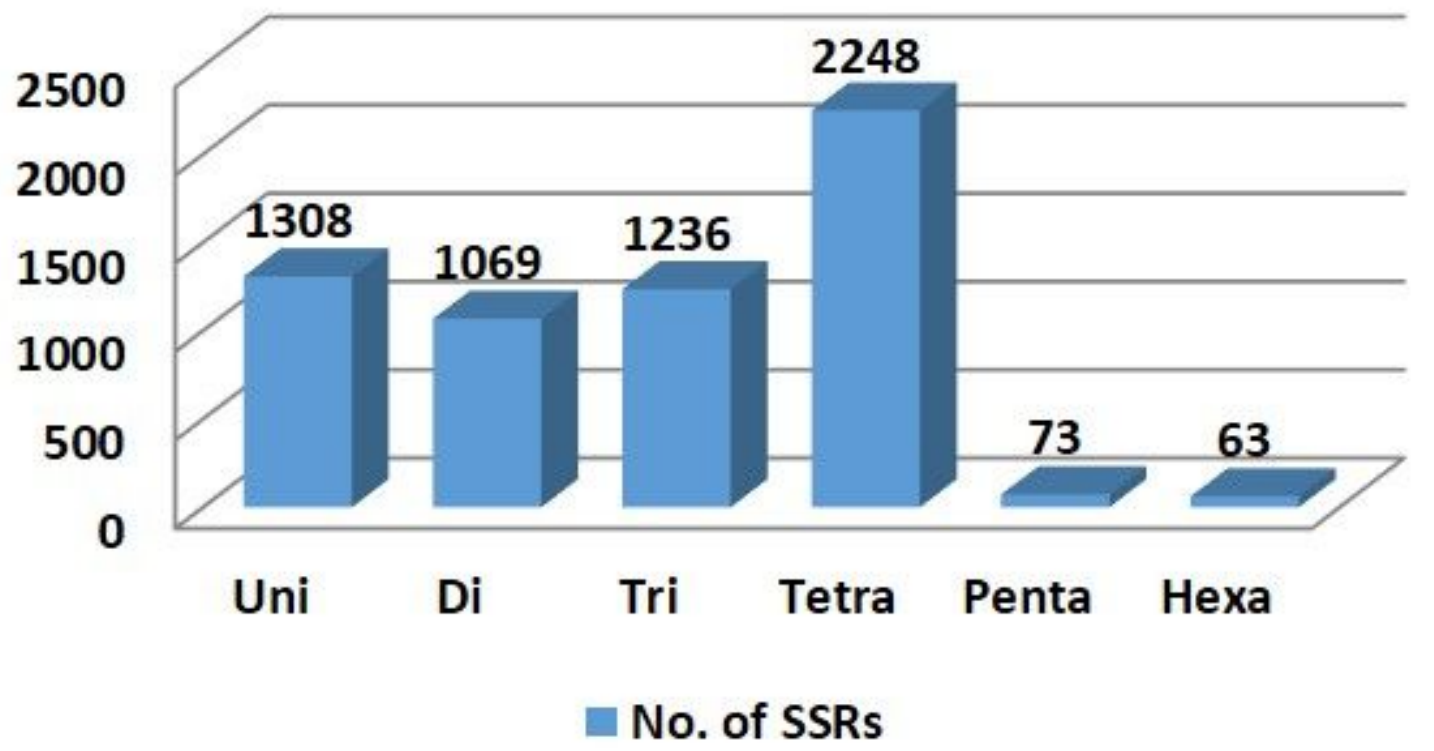

Figure 4 
Number of simple sequence repeats with uni, di, tri, tetra, penta, and hexanucleotide in the B. sorokiniana genome.

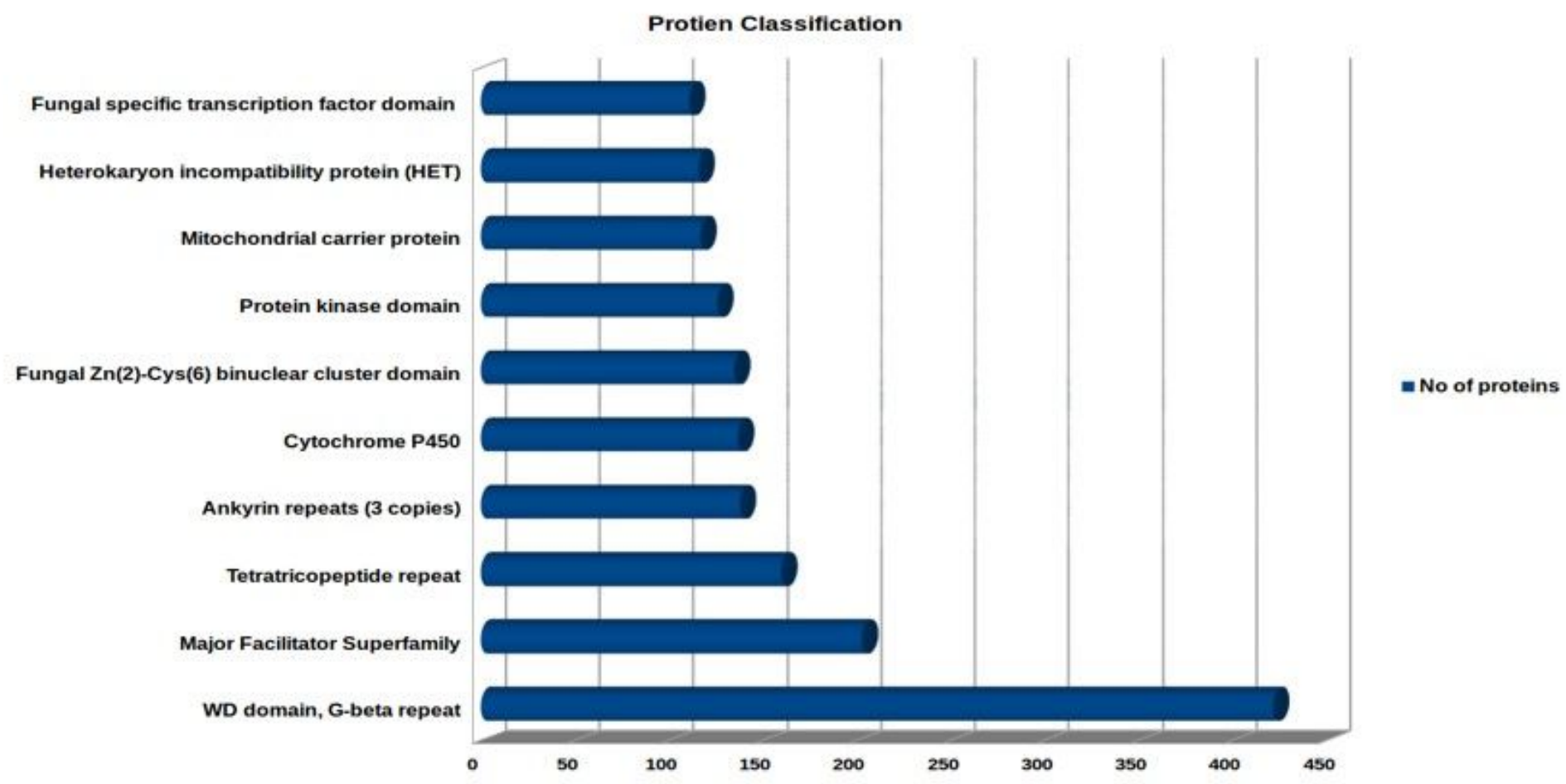

\section{Figure 5}

Top 10 PFam domain distribution in the genome of Bipolaris sorokiniana. 


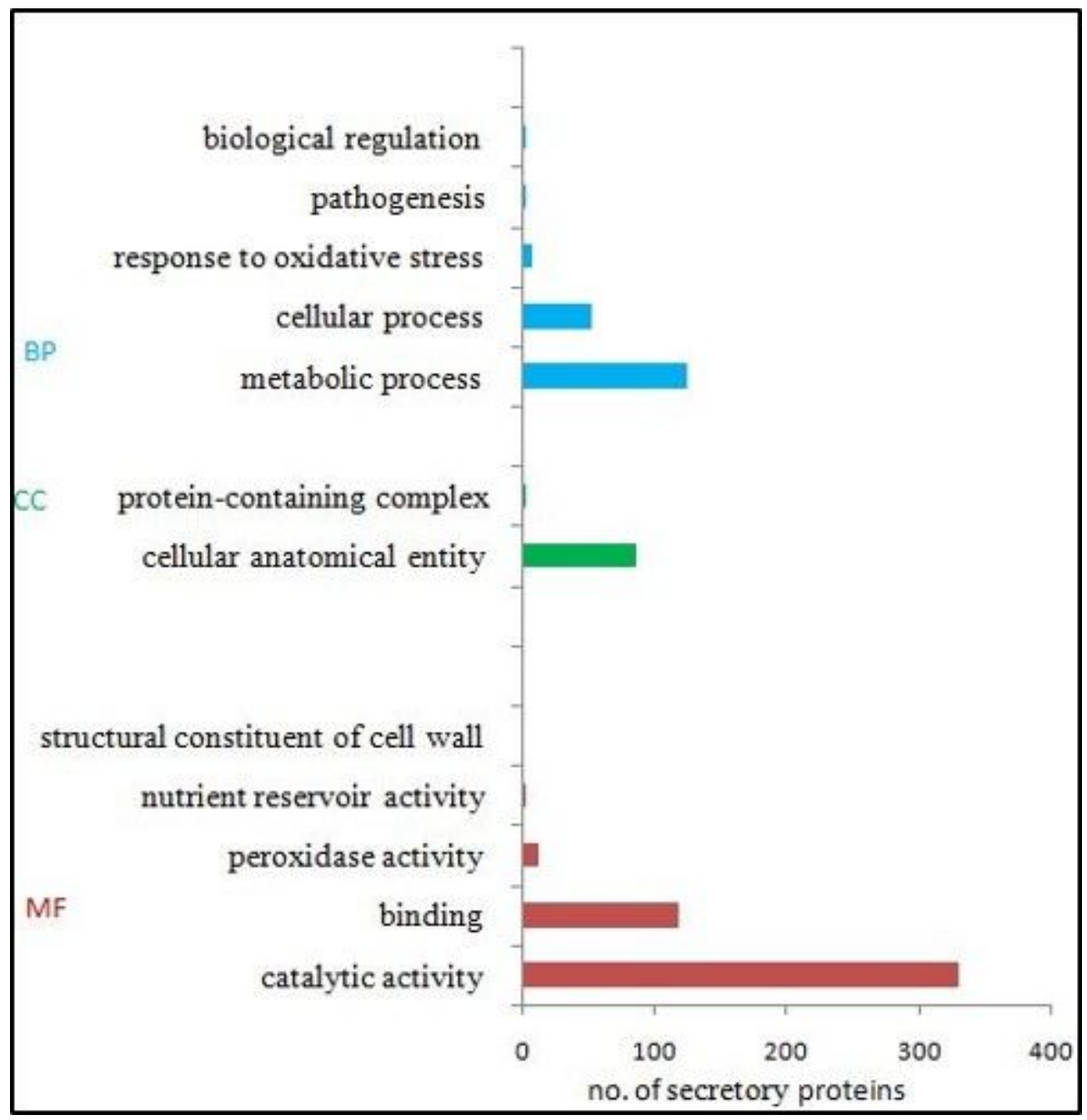

\section{Figure 6}

Functional annotation of the Bipolaris sorokiniana secretome showing topmost category Viz. MFmolecular function; CC- cellular component; BP- biological process. 


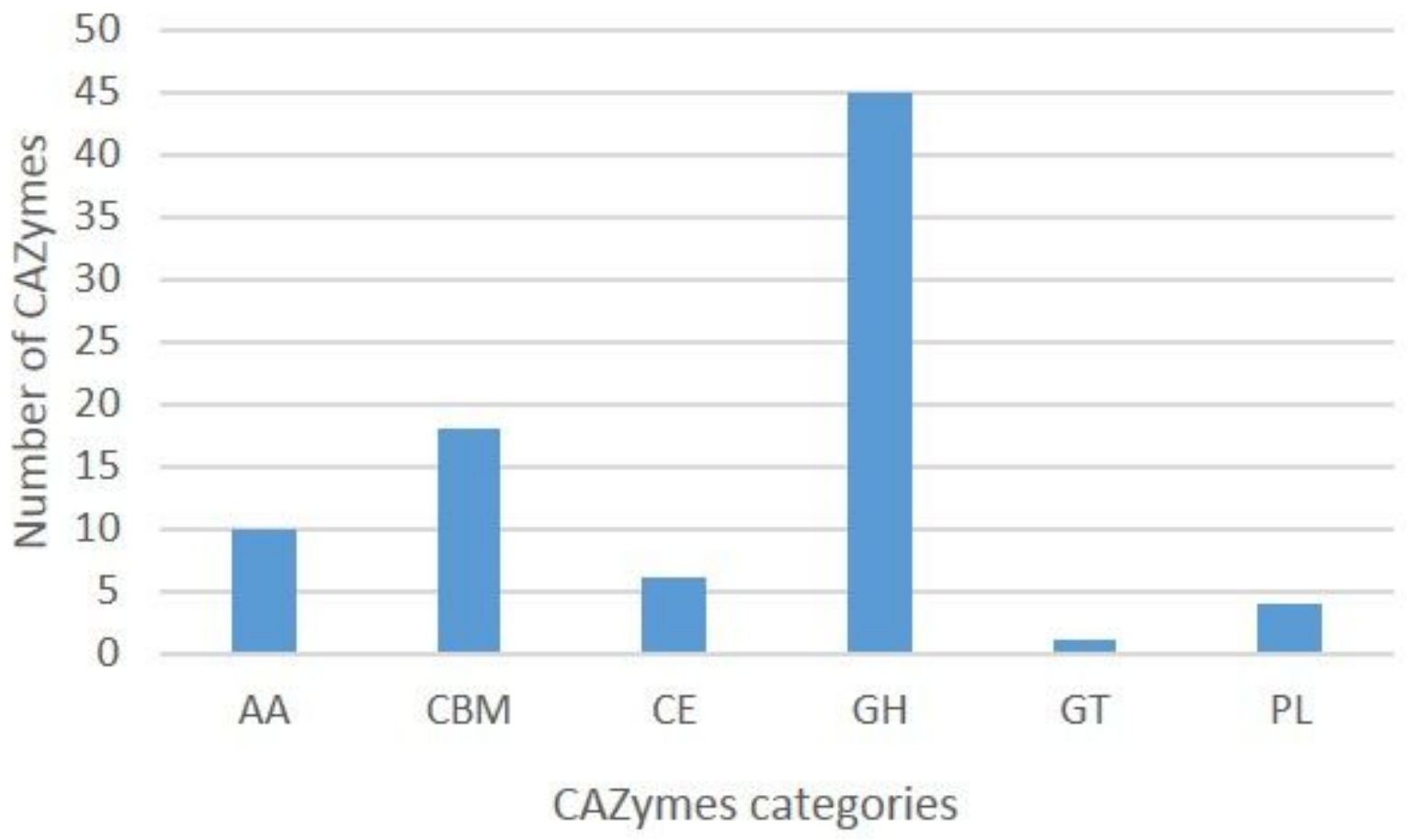

Figure 7

CAZymes class annotation distribution of Bipolaris sorokiniana BS112 genome. AA- Auxiliary activities; CBM- Carbohydrate Binding Modules; CE- Carbohydrate esterase; GH- Glycoside hydrolases; GT- Glcosyl transferases; PL- Polysaccharide lyases.

(a)

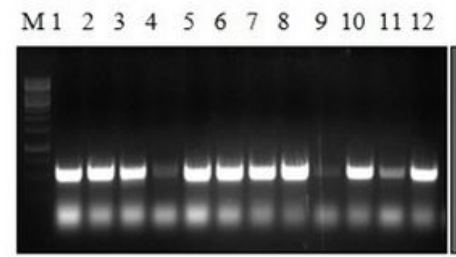

M $131415161718192021 \quad 22 \quad$ M $23 \quad 24 \quad 25 \quad 26 \quad 27 \quad 28 \quad 29$

M $30313233343536 \quad 373839$

(b)
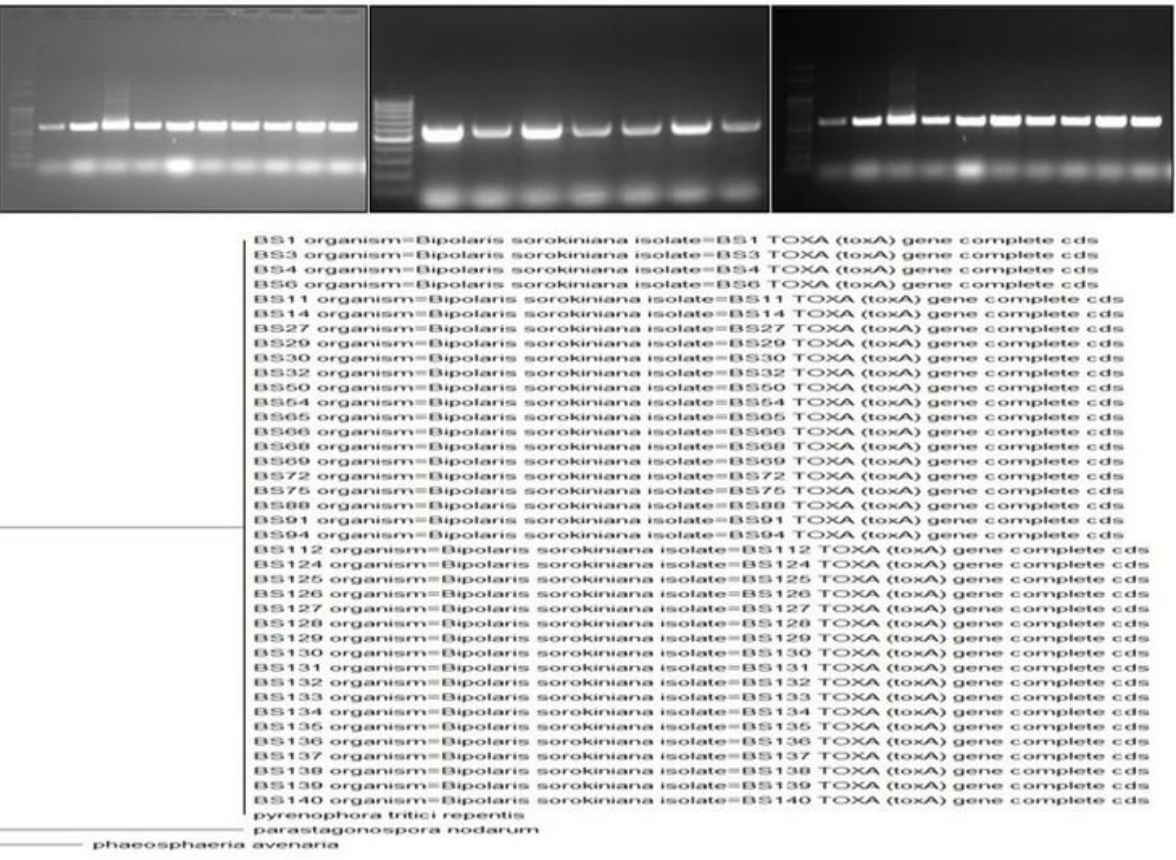


\section{Figure 8}

(a) Amplification profile of 39 isolates of $B$. sorokiniana harbouring ToxA gene. M (100bp bioprep marker), 1-BS1, 2-BS3, 3-BS4, 4-BS6, 5-BS11, 6-BS14, 7-BS27, 8-BS29, 9-BS30, 10-BS32, 11-BS50, 12 BS54, 13-BS65, 14-BS66, 15-BS68, 16-BS69, 17-BS72, 18-BS75, 19-BS88, 20-BS91, 21-BS94, 22-BS112, 23-BS124, 24-BS125, 25-BS126, 26-BS127, 27-BS128, 28-BS129, 29-BS130, 30-BS131, 31-BS132, 32BS133, 33-BS134, 34-BS135, 35-BS136, 36-BS137, 37-BS138, 38-BS139, 39-BS140; (b) Phylogenetic tree of different isolates of B. sorokiniana, Pyrenophora tritici repentis, Phaeosphaeria avenaria and Parastagonospora nodorum. 
Bsroxa

AusBsToxal

AusBSTOXA:

ptr_Toxa

Bnt_Toxa

Bsroxa

Auabstoxal

AusBgToxa2

ptr_Toxi

sn4_Toxa

Bsroxa

AusBsToxal

Auasstoxa2

ptr_Toxa

Bn4_Toxh

Bgroxa

AusBgToxa!

AusBsToxa?

ptr_Toxa

Bns_Toxa

Bszoxa

AuaBsToxal

AuaBsToxa2

ptr_Toxa

Sn4_Toxa

Bsroxa

AuabsToxa1

Auabstoxa:

ptr_Toxa

gnt_Toxa

BsFoxa

AuaBsToxal

AuaBSToxa2

ptr_Toxa

Snt_Toxe

Bszoxa

AusBstoxal

AusBsToxe.2

ptr_Toxa

gn4_Toxa

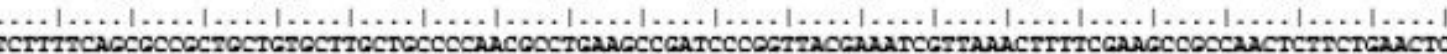

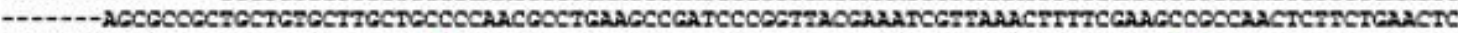

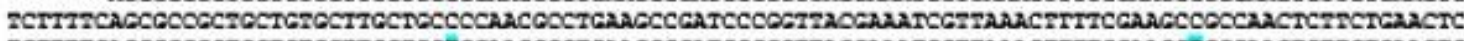

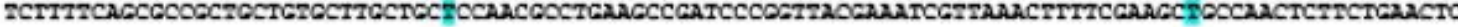

$\begin{array}{lllllllll}310 & 320 & 330 & 340 & 350 & 360 & 370 & 390 & 390\end{array}$

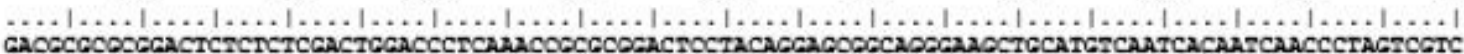

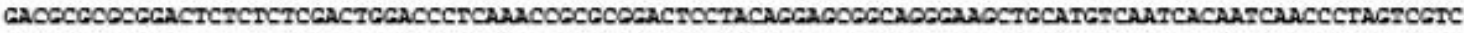

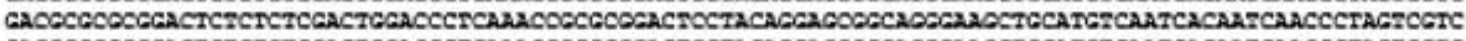

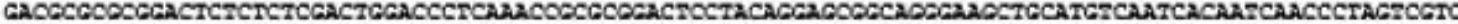

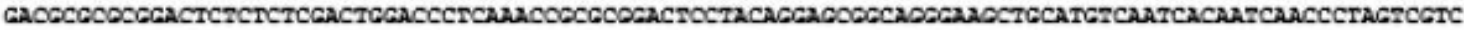

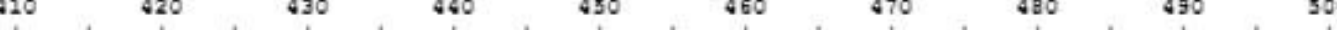

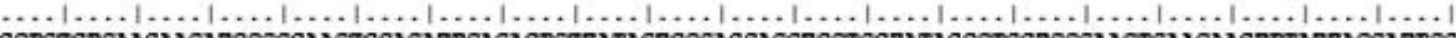

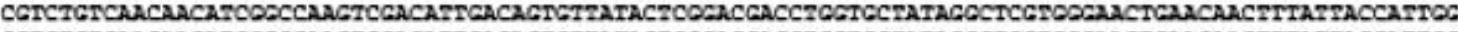

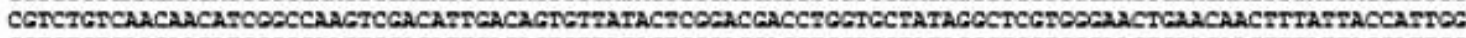

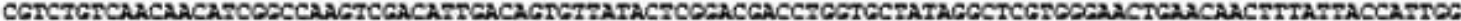

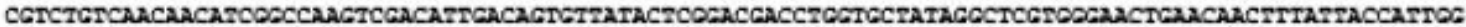

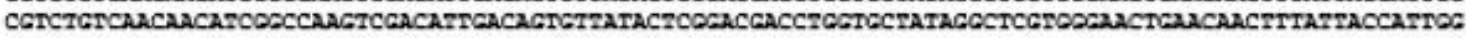

$\begin{array}{llllllllll}510 & 520 & 530 & 540 & 550 & 560 & 570 & 530 & 590 & 600\end{array}$

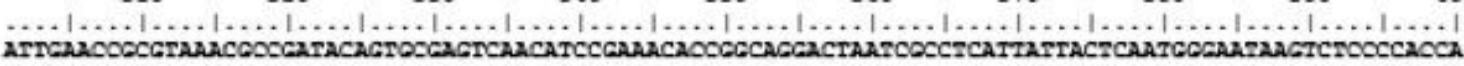

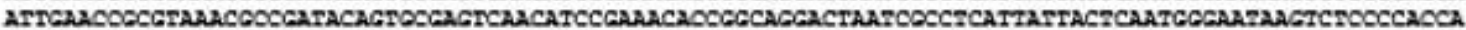

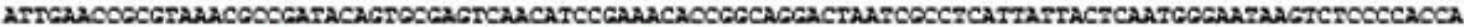

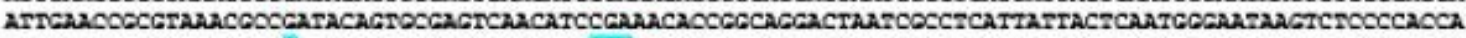

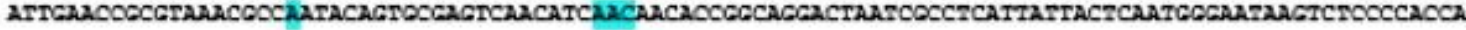

$\begin{array}{lllllllll}610 & 620 & 630 & 640 & 650 & 660 & 670 & 680 & 690\end{array}$

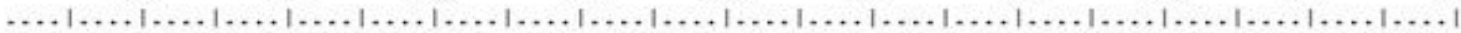

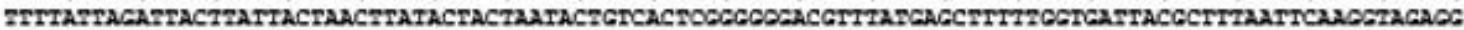

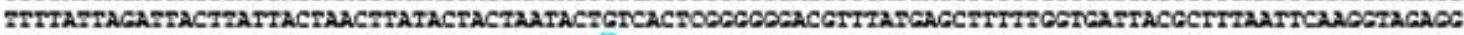

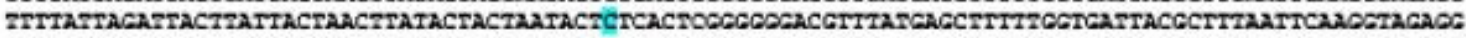

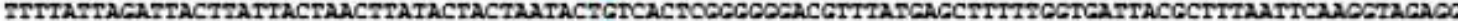

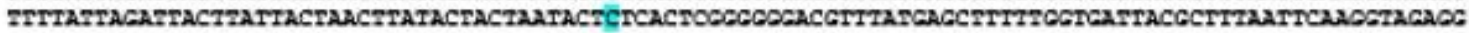

$\begin{array}{lllllllll}720 & 720 & 730 & 740 & 750 & 760 & 770 & 730 & 790\end{array}$

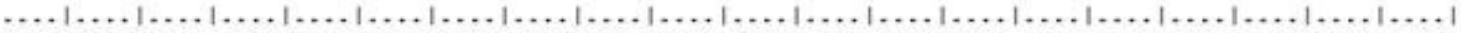

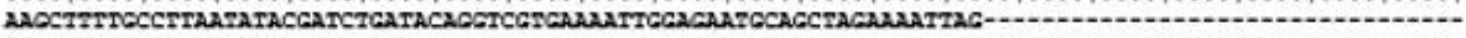

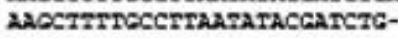

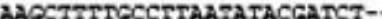

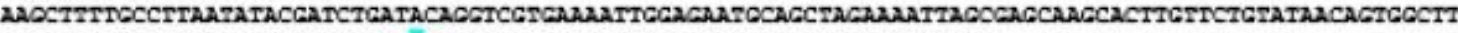

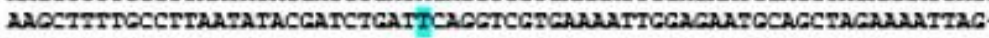

$810 \quad 820 \quad 830$

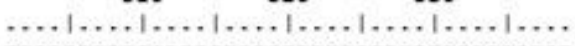

BSToxA

AusBsToxal

AuassToxa2

ptr_Toxa

Snt_Toxa

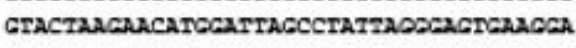

\section{Figure 9}

Nucleotide sequences of Bipolaris sorokiniana ToxA gene from India (BSToxA) and Australia (AusBSToxA1 and AusBSToxA1) aligned to Pyrenophora tritici repentis (ptr_ToxA) and Parastagonospora nodorum (Sn4_ToxA). 
(a)

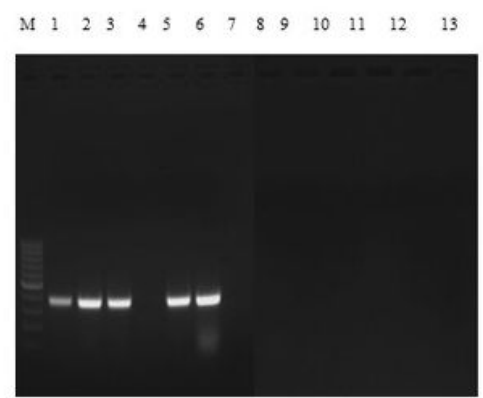

(b)

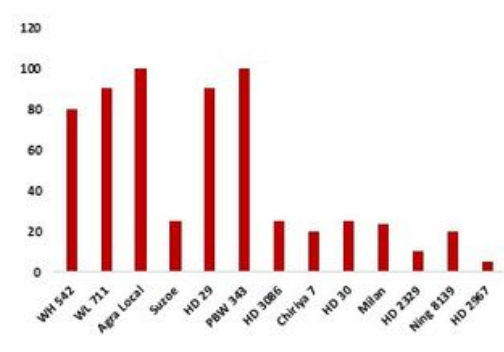

Figure 10

(a) Amplification profile of 13 wheat genotypes harboring Tsn1 gene. 1-WH 542, 2-WL 711, 3-Agra Local, 4-Suzoe, 5- HD 29, 6- PBW 343, 7-HD 3086, 8-Chiriya 7, 9-HD 30, 10-Milan, 11-HD 2329, 12- Ning 8139, 13HD 2967; (b) Average Disease Index (ADI) of 13 wheat genotypes harboring Tsn1 gene. 

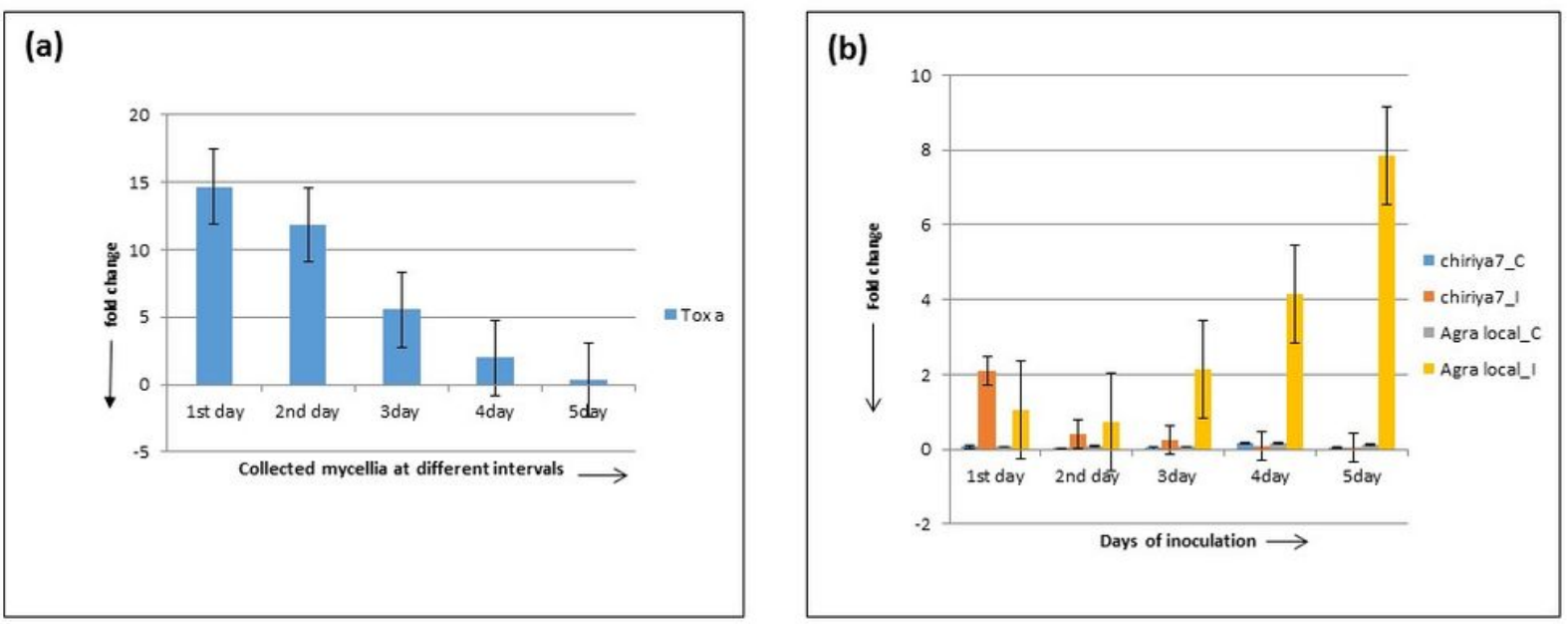

\section{Figure 11}

(a) In vitro expression of ToxA gene in BS112 at different time intervals; (b) In vivo expression of ToxA gene after inoculation on two different genotypes at different time intervals.

\section{Supplementary Files}

This is a list of supplementary files associated with this preprint. Click to download.

- Additionalfile1.xlsx

- Additionalfile2.xls

- Additionalfile3.xls

- Additionalfile4.xls

- Additionalfile5.xlsx

- Additionalfile6.xls

- Additionalfile7.xls

- Additionalfile8fig.S1.jpg 